Int. J. Dev. Biol. 56: 411-423 (2012)

doi: $10.1387 / \mathrm{ijdb} .120086 \mathrm{bg}$

\title{
Hydra, a fruitful model system for 270 years
}

\author{
BRIGITTE GALLIOT* \\ Department of Genetics and Evolution, University of Geneva, Switzerland
}

\begin{abstract}
The discovery of Hydra regeneration by Abraham Trembley in 1744 promoted much scientific curiosity thanks to his clever design of experimental strategies away from the natural environment. Since then, this little freshwater cnidarian polyp flourished as a potent and fruitful model system. Here, we review some general biological questions that benefitted from Hydra research, such as the nature of embryogenesis, neurogenesis, induction by organizers, sex reversal, symbiosis, aging, feeding behavior, light regulation, multipotency of somatic stem cells, temperature-induced cell death, neuronal transdifferentiation, to cite only a few. To understand how phenotypes arise, theoricists also chose Hydra to model patterning and morphogenetic events, providing helpful concepts such as reaction-diffusion, positional information, and autocatalysis combined with lateral inhibition. Indeed, throughout these past $\mathbf{2 7 0}$ years, scientists used transplantation and grafting experiments, together with tissue, cell and molecular labelings, as well as biochemical procedures, in order to establish the solid foundations of cell and developmental biology. Nowadays, thanks to transgenic, genomic and proteomic tools, Hydra remains a promising model for these fields, but also for addressing novel questions such as evolutionary mechanisms, maintenance of dynamic homeostasis, regulation of stemness, functions of autophagy, cell death, stress response, innate immunity, bioactive compounds in ecosystems, ecotoxicant sensing and science communication.
\end{abstract}

KEY WORDS: historical perspective, transplantation, modeling, developmental reactivation, Hydra regeneration, multipotency, stemness, symbiosis, environment

\section{The heuristic value of the Hydra model system}

In the early 18th century the word biology was not yet in use but the nature of living organisms and their evolutionary relationships was the focus of interest for philosophers and naturalists, as evidenced by their pioneering efforts to develop new tools such as microscopes that would allow finer observation (Palm, 1996). The microscopic observation of organisms taken in the field undoubtedly helped develop morphological keys to sort between the animal and vegetal kingdoms and to group them into phyla (Linnaeus, 1758). Among the ambiguous species that could not be easily classified were the seawater corals that looked like flowers (Watson, 1753; McConnell, 1990) and the freshwater Hydra polyp that was considered to exhibit both animal and vegetal features. For example, Hydra easily reproduces asexually through budding, a trait frequently assigned to plants or fungi.

Having observed some Hydra polyps in a pond, Abraham Trembley (1710-1784) (who had received a PhD in mathematics from the University of Geneva (Switzerland) and was now educating the children of the Count of Bentick in the Netherlands) decided to solve that problem by testing their capacity to regenerate, assuming that if Hydra regenerates, then it should be considered a plant, but if it does not, then it should belong to the animal kingdom (Trembley, 1744). Thus, he cut this little organism into two pieces and observed during the next days that the Hydra had regenerated any cut away part. However, Trembley did not conclude that it was a plant as he had carefully noted several behaviors that were not consistent with it being a plant. Indeed he noted that Hydra actively capture their food with their tentacles, contract upon touch, slowly but efficiently walk (Trembley, 1744). All these behaviors that indicate the presence of nervous and digestive systems, are clear hallmarks of animals traits.

Abraham Trembley understood that that he had made a major discovery, i.e. an animal is able to fully regenerate any missing part of its body, and thereafter spent much time and energy convincing his peers (Réaumur, 1741; Trembley, 1744; Ratcliff, 2004, 2012). Later on it became clear that together with jellyfish, sea anemones

Abbreviations used in this paper: ECM, extra-cellular matrix; HA, head activation; HI, head inhibition; i-cells, interstitial cells.

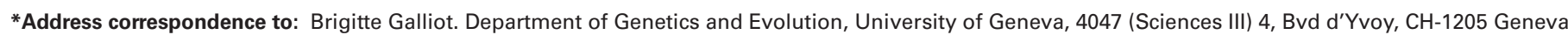
Switzerland. Fax: + 41 (0)22.379.33.40. e-mail: brigitte.galliot@ unige.ch - web: http://genev.unige.ch/en/users/Brigitte-Galliot/unit
}

Accepted: 13 July 2012. Final, author-corrected PDF published online: 27 July 2012.

ISSN: Online 1696-3547, Print 0214-6282

(c) 2012 UBC Press

Printed in Spain 


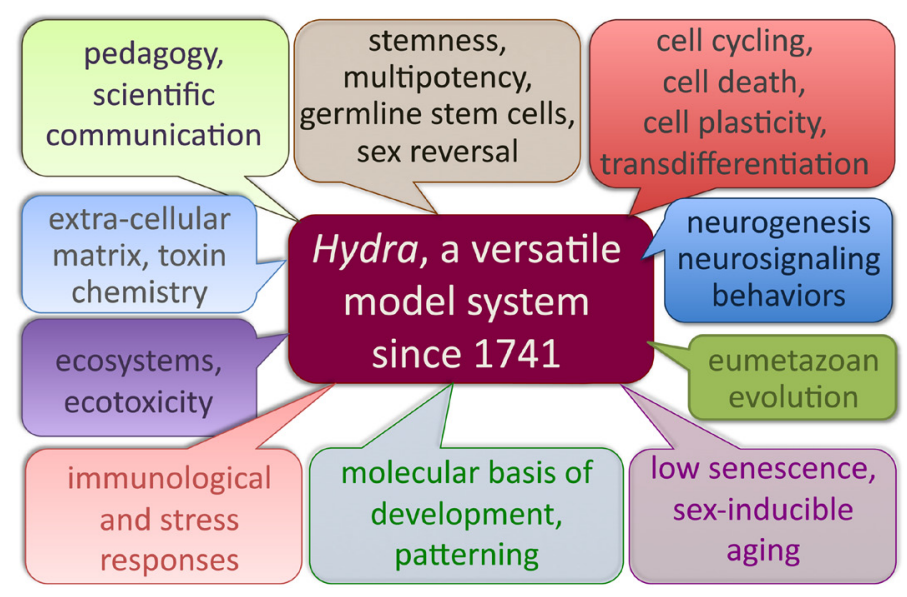

Fig. 1. The multiple aspects of biology that can be addressed thanks to the Hydra model system.

and corals, Hydra form a sister phylum to Bilateria named Cnidaria (Haeckel, 1896; Hyman, 1940; Collins et al., 2006). In this issue Marc Ratcliff highlights a novel and influential aspect of Abraham Trembley's contribution to the development of experimental sciences. Indeed, with the accurate analysis of Hydra behaviors and tissues, he set up the tools and the conditions to investigate the mysterious laws of aquatic life in his study and no longer in the field, promoting thus the development of marine biology as an experimental, rather than solely observational, science (Ratcliff, 2012). This article is illustrated with historical drawings archived at the Public Library of Geneva, selected in 2010 for an exhibition entitled "Abraham Trembley and the birth of marine zoology".

\section{Hydraa a model system to understand how developmen- tal programs remain active or activable in adult organisms}

In the late 19th century Hydra together with other hydromedusae emerged as fruitful model systems for physiology (Greenwood, 1888), cell biology (Weismann, 1883; Hadzi, 1909) and developmental biology (Rand, 1899; Tannreuther, 1908; Browne, 1909; Hyman, 1928). Indeed, Hydra polyps provided an experimental framework to study the mechanisms that regulate the maintenance of homeostasis even in extreme conditions (starvation, overfeeding) as well as those driving the reactivation of developmental programs after bisection or during budding (Fig. 1, Fig. 3).

\section{Transplantation strategies to measure organizing activities and regenerative potential}

Transplantation experiments performed on Hydra polyps were quite common at the turn of the $20^{\text {th }}$ century. Ethel Browne, inspired by the recent results of her colleagues, developed a novel strategy that allowed her to discover "induction" (Browne, 1909) an essential principle in embryology. Although she never used the word "induction" herself, she understood and demonstrated the complexity of this process. First she cut a "tentacle with a small bit of peristome (head tissue) at its basis" from the donor and inserted it in a slit made along the body column of the host. In the following days she observed the development of an ectopic "hydranth" on the body column of the host, in 10 grafts out of 13 demonstrating, thus the robustness of the process (see her drawings reproduced in Bossert and Galliot in this issue).
Second, she wanted to trace the origin of the cells forming this ectopic "hydranth", and for that purpose she got the idea to perform transplantation between pigmented and depigmented Hydra of the same species. Indeed, a recent report had just identified a simple way to get rid of the "green bodies" of Hydra viridis (Whitney, 1907). That way she nicely demonstrated that the grafted tissue actually recruits cells from the host to form the ectopically developing structure and she wrote: "From these experiments the conclusion must be drawn that it is principally the material of the body wall of the stock and not the hydranth material of the graft that forms the new hydranth" (see Fig. 2). She also showed that in addition to the apical region of the polyp, the regenerating head and the presumptive head region in the growing bud do exhibit organizer activity.

This important work was published in 1909, 15 years before the report of Spemann and Mangold on the organizer activity of the dorsal lip of the amphibian embryo (Spemann and Mangold, 1924) Unfortunately Spemann who was aware of Ethel Browne's work and might have been inspired by her experiments, never cited her work (Lenhoff, 1991). Despite this lack of recognition, her transplantation approach opened an avenue and largely contributed to promote Hydra as a powerful model in developmental biology (Fig. 3).

\section{Parallel Head activation (HA) and Head inhibition (HI) gradients along the body column}

Because of the multiple types of grafting she tested, Ethel Browne understood that the grafted tissue provides the stimulus to develop an ectopic axis, whereas the cells of the host predominantly contribute to the formation of the induced structure, two criteria that fulfills the definition of an organizer (Fig. 2). However she did not figure out that the host might be able to inhibit the activity of the grafted tissue. Twenty years later the concepts of Head Activation and Head Inhibition emerged, represented as one pair of parallel gradients (Mutz, 1930; Child, 1932; Yao, 1945). Later on Gerald Webster and Lewis Wolpert in London, Harry MacWilliams in Worcester, and Tsutomu Sugiyama in Mishima, quantified these graded activities along the body column, showing maximal HA and $\mathrm{HI}$ levels at the apex (Webster, 1966a, b; Sugiyama, 1982; MacWilliams, 1983a, b; Takano and Sugiyama, 1983).

In the 1970s, with the aim of identifying the genetic basis of developmental mechanisms in Hydra, Toshitaka Fujisawa and Tsutomu Sugiyama decided to perform a screen to isolate Hydra mutants (Sugiyama and Fugisawa, 1977a, b; Sugiyama and Fujisawa, $1978 a, b)$. Hiroshi Shimizu in this issue recapitulates the results they obtained by measuring precisely thanks to lateral transplantation experiments the slopes of the $\mathrm{HA}$ and $\mathrm{HI}$ gradients along the body column of a collection of Hydra strains isolated from the field or produced through breeding (Shimizu, 2012). To identify the cell types regulating $\mathrm{HA}$ and $\mathrm{HI}$, Fujisawa and Sugiyama then applied the reaggregation technique developed by Richard Campbell (Marcum and Campbell, 1978) to produce chimeric animals made up of cell lineages isolated from highly different strains in terms of $\mathrm{HA}$ and $\mathrm{HI}$ slopes. With this sophisticated strategy they could thus deduce the role of each cell lineage and reached the conclusion that $\mathrm{HI}$ is primarily under the control of the endodermal epithelial cells with a slight modulation by the interstitial cells, whereas the $\mathrm{HA}$ gradient is directed by the ectodermal epithelial cells (Takano and Sugiyama, 1984; Shimizu, 2012). 


\section{Apical organizing activity versus self-organizing activity of the body column}

Abody of corroborating data obtained from lateral transplantation of tissues from the upper body column stresses that head formation, in this context, does not rely on organizer activity but rather on the self-organizing property of the grafted tissue(Yao, 1945; MacWilliams, 1983b; Broun and Bode, 2002). The main difference is the recruitment of host cells by the grafted tissue, and indeed the analysis of the tissues of the ectopic axis shows that upon grafting of the upper body column, the ectopic Hydra contains predominantly cells from the donor and not from the host, proving the low inductive activity of the graft. This is in sharp contrast with the results obtained when tissues from the hypostome, the head-regenerating tip or the growing bud are grafted (see above). The transient contact between a hypostome and the body column of the host actually suffices to induce an ectopic axis, suggesting that signaling molecules (morphogens) are released during the period of contact (Broun and Bode, 2002). Wnt3, the ligand of the canonical Wnt pathway appears as the signal that sets up the organizing activity in the head (Broun et al., 2005; Gee et al., 2010). In this issue, Hans Bode details the criteria that define the head organizer and discusses the molecular mechanisms that might distinguish induction from self-organization (Bode, 2012).

\section{Theoretical modeling of the principles of developmental biol- ogy in Hydra}

The tentacles immutably organized as a ring in Hydra likely inspired Alan Turing as he took this example of patterning, among others, to develop his model of reaction-diffusion and propose it as a model for the chemical basis of morphogenesis (Turing, 1952). This model of reaction-diffusion was itself used to develop several models describing positional information in Hydra, taking into accounts the two pairs of activation and inhibition gradients that had been characterized experimentally (Wolpert, 1969; Gierer and Meinhardt, 1972). With the idea of identifying general principles for development, i.e. to translate the genetic information into patterns, Lewis Wolpert considered hydroid regeneration, sea urchin gastrulation, epidermis patterning in insects and chick limb development to propose the unifying concept of positional information, whereby each cell receives an address corresponding to its position in a developing tissue/organ, i.e. in a co-ordinate system defined by reference points and boundaries (Wolpert, 1969). If Hydra is considered as a unipolar system, then the reference point for any cell along the body column would be the hypostome and a graded distribution of

Fig. 2. Representative transplantation experiments performed by Ethel Browne between pigmented and depigmented Hydra polyps. To depigment Hydra viridis that contain symbiotic algae (green), the polyps are treated with $0.5 \%$ glycerine for three weeks to become "artificial white hydra." All grafts were performed laterally at mid-body level, except when specified. (Exp 42) White tentacle with base (arrow) grafted on a green hydra showing the formation of an ectopic hydra with an important contribution of the host cells. (Exp 43) White tentacle with base grafted in the foot of a green hydra resulting in the formation of a minute hydranth. (Exp 44) Green tentacle without base grafted into a white hydra showing the lack of inducing activity and the absorbtion of the grafted tissue. (Exp 45) Graft of a ring of green tissue (body column) that remains as a patch, with no inducing activity. (Exp 46) Graft of a complete green hydra on a white host showing that the green hydra keeps its individuality and gets displaced towards the basal pole. (Exp 47) Basal half of a green hydra grafted by its apical side at mid-body level on a white hydra; after 6 days this basal half has regenerated a head and is close to detach from the host. substances from the hypostome to any cell along the axis would provide this positional information. In fact there are two poles in Hydra and this positional information is supposed to be regulated by two pairs of linear parallel gradients, running opposite of each other, one for head activation / head inhibition and the second for foot activation / foot inhibition.

Few years later Alfred Gierer and Hans Meinhardt reinterpreted the Hydra transplantation data produced in the laboratory of Lewis Wolpert and deduced a molecular theory of biological pattern formation based on autocatalysis and lateral inhibition that integrated the concepts developed by Turing first and later by Wolpert (Gierer and Meinhardt, 1972). In short they proposed a non-linear activation / inhibition model where the cross-talk between two types of substances would drive morphogenesis, activators that act locally and self-enhance their activity (auto-catalytic), inhibitors that repress activators (cross-catalytic) over long-range distance. If one assumes that these two types of molecules are distributed in the tissue with different concentrations and different source densities, then this activation-inhibition model, which is based on non-linear interactions, would support the two phases of morphogenesis, a

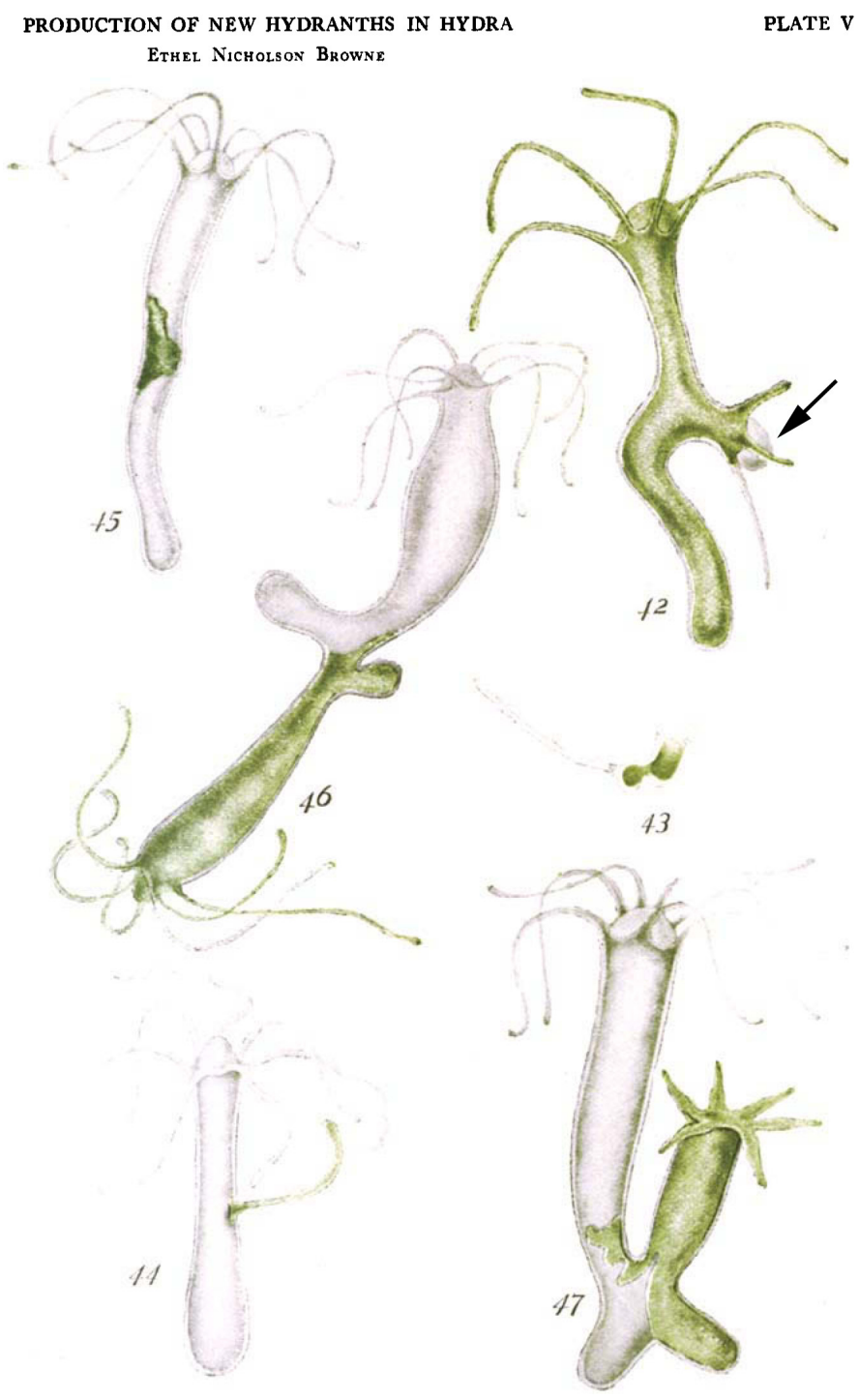

The Journal of Experimental. Zoölogy, vol. vil.

Ricciol. del. 
fast one to establish a primary pattern (for example the organizing activity developed in few hours in the head-regenerating tip) and a slower one to differentiate the definitive structure. In case of Hydra, this model explains how de-novo patterns can arise, how any part of the body column can regenerate a complete animal.

In this issue, Alfred Gierer tells us how he moved from physics to microbiology, then to developmental biology, selecting the Hydra model system to develop concepts unifying the principles of development that can be applied to organisms more complex than Hydra, and finally to neurobiology (Gierer, 2012). He also discusses the role of mathematics to understand how cells generate real shapes, like stable cell sheets or evaginated structures. In the following review, Hans Meinhardt provides more experimental data that support the activation-inhibition model (Meinhardt, 2012), as the work of Ueli Technau et al., who showed on regenerating aggregates that activation concerns about 10 to 15 cells, i.e. a 100 $\mu \mathrm{m}$ large region, whereas inhibitory activity extends over a 800-900 $\mu \mathrm{m}$ distance (Technau et al., 2000). At the molecular level, Wnt signals (specially Wnt3) fulfill the requirements of an activator, however inhibitor molecules that would fit the model remain to be identified in Hydra. In developing vertebrates, some activator/inhibitor couples such as Nodal/Lefty, involved in mesoderm formation and left/right patterning, fit well with the activation-inhibition model, indicating that indeed this model support developmental processes in eumetazoans.

\section{Hydra - a model system for aging studies}

An initial study on aging in Hydra was performed by Paul Brien in Paris who wanted to investigate the crosstalk between the asexual and sexual modes of reproduction (Brien, 1953). In two species, Hydra vulgaris and Hydra viridis, Brien noted that budding persists even in animals that undergo sexual differentiation; he also recorded that these animals did not seem to loose their fitness when surveyed over several years. In case of Hydra oligactis the result was different, animals exposed to cold induce their sexual differentiation, then rapidly stopped budding and after having laid eggs, become "exhausted" after three months and die. Although Brien did not use the words senescence or aging, two main conclusions could be deduced from his observations: 1) Hydra polyps maintained at room temperature exhibit no or very limited senescence, 2) Hydra oligactis that undergo sexual differentiation upon cold induction, rapidly die, providing thus a system where aging is inducible. These two aspects were indeed confirmed by independent studies: first the lack of senescence was tested in North America on cohorts of asexual Hydra vulgaris by Martinez (1998), second the inducibility of aging in Hydra oligactis was reproduced in Japan by Yoshida et al. (2006). In this issue Daniel Martinez and Diane Bridge discuss the role of proteins involved in the cellular stress response that are required to maintain homeostasis over a long term (Martinez and Bridge, 2012).

\section{Hydra - a model system for stem cell biology}

The biology of stem cells in Hydra: multipotency, sex determination and stemness

Hydra provides unique experimental conditions to investigate the biology of stem cells. Three distinct populations of continuously proliferating stem cells were characterized, epithelial endodermal and epithelial ectodermal stem cells that are each unipotent, i.e. providing epithelial cells that acquire specific features in the apical and basal regions. These epithelial stem cells that cannot replace each other, form two epidermal /gastrodermal sheets linked together by the extra-cellular matrix (named mesoglea) (Wood, 1961; Lentz, 1966; Sarras, 2012). The third stem cell population named interstitial stem cells, already identified as progenitors of the nematocyte lineage by Brauer (Brauer, 1891), actually provide progenitors for all cells of the nervous system, including the mechanosensory cells (named nematocytes or cnidocytes), but also for the gland cells of the digestive tract and for the germ cells when the animals follow the sexual cycle (Tardent, 1954; Brien and Reniers-Decoen, 1955; Burnett and Diehl, 1964; Diehl and Burnett, 1964; David and Murphy, 1977; Sugiyama and Fujisawa, 1978a; Bode et al., 1987; Bosch and Davis, 1987; Bode, 1996). This means that the interstitial stem cells provide both somatic cell lineages and germ cells all along the life of the animal. Their self-renewal property was proven in cloning experiments performed on aggregates made of cells treated with nitrogen mustard that are no longer able to proliferate, and in transplantation experiments performed on "epithelial" Hydra that no longer contain interstitial cells. In this issue three articles review our current knowledge about stem cells in Hydra, the first one by Charles David on the multipotency of the interstitial cells (David, 2012), the second by Chiemi Nishimiya-Fujisawa on the germline stem cells and the sex determination in Hydra (Nishimiya-Fujisawa and Kobayashi, 2012) and the third one by Bert Hobmayer and colleagues who discuss the stemness-related genes that might help distinguish between these three stem cell populations (Hobmayer et al., 2012).

\section{The Hydractinia model system, a close cousin but marine and colonial}

Sexual development is not easily amenable to experimentation in Hydra and marine cnidarian organisms that provide an inducible system for sexual development always offered valuable experimental alternatives (Frank et al., 2001; Galliot and Schmid, 2002; Houliston et al., 2010). One of the best examples is the marine colonial hydrozoan Hydractinia used by August Weizmann to identify the germ plasm that he distinguished from the somatic stem cells. Weizmann thus proposed the germ plasm theory whereby only germ cells and not somatic cells contribute to the transmission of characters (Weismann, 1883). Today Hydractinia is a fruitful model system for stem cell biology as seen by the recent elegant work done by Millane et al., who ectopically expressed an Oct-4 related protein named Polynem in the epithelial cells and thus triggered the formation of neoplasm by reprogramming these epithelial cells to pluripotent interstitial cells (Millane et al., 2011). In this issue, Günter Plickert, Uri Frank and Werner Müller discuss the strength of the Hydractinia model system, not only for deciphering the mechanisms establishing stemness and cell reprogramming, but also, for addressing the role of Wnt signaling in developmental processes as well as the evolution of histo-compatibility (Plickert et al., 2012).

\section{Cell to tissue signaling and vice-versa}

Cell culture has never been successfully established from any cnidarian organism thus far. However, Hydra provides an experimental model system where cell behavior can be monitored in the context of an intact adult tissue. Indeed, Hydra is an organism that behaves as a whole, that can reactivate developmental programs 
in a variety of contexts and that can now be manipulated so that as any cell lineage can be labeled thanks to the transgenic procedures recently established in the lab of Thomas Bosch (Wittlieb et al., 2006; Khalturin et al., 2007; Siebert et al., 2008). All these properties would be lost in cell culture, which thus no longer appears essential compared to the advantages provided by a 4D physiological and developmental system, and the possibility anyhow to test in heterologous systems the molecular properties of the Hydragenes.

\section{Setting up the boundaries in adult and developing Hydra}

In this issue Angelika Boettger and Monika Hassel provide arguments to uncover in Hydra some robust eumetazoan innovations that allow to set up boundaries between different morphogenetic fields (Bottger and Hassel, 2012). Firstly, and despite its apparent

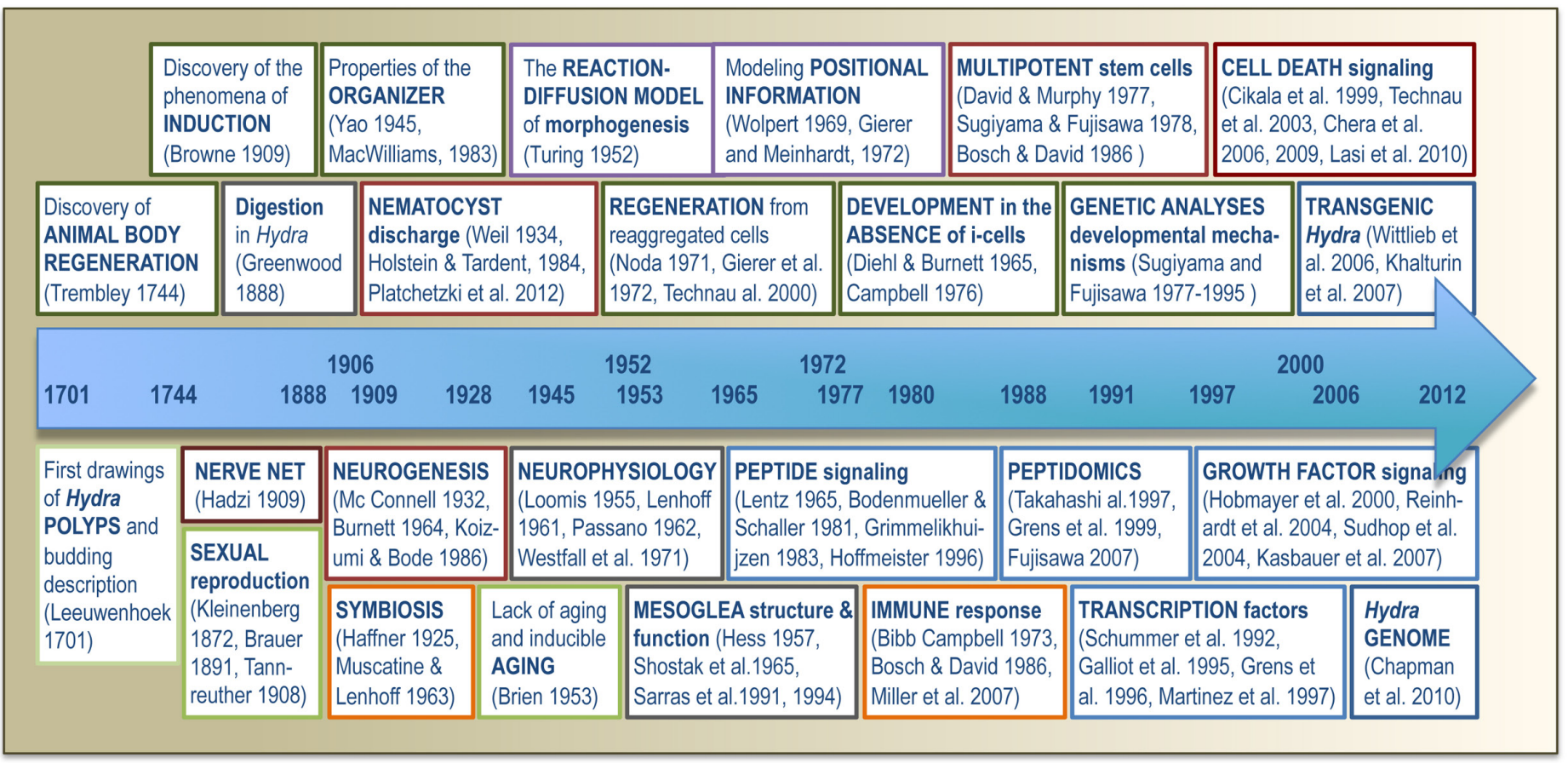

Fig. 3. Time line overview of the $\mathbf{3 0 0}$ first years of $\boldsymbol{H y d r a}$ research. This timeline lists key findings in Hydra research and the author apologizes for not referring to more findings, due to space constraints. See the indicated authors for a more complete reviewing of the following topics: the first microscopic view of Hydra and budding (Palm, 1996; Tannreuther, 1908; Hyman, 1928; Otto and Campbell, 1977a; Bottger and Hassel, 2012); the discovery of Hydra regeneration and its scientific impact (Trembley, 1744; Lenhoff and Lenhoff, 1986; Gierer, 2012; Ratcliff, 2012); digestion (Greenwood, 1888; Chera et al., 2006; Sher et al., 2008; Rachamim and Sher, 2012); sex determination, sex reversal and embryogenesis (Kleinenberg, 1872; Brauer, 1891; Hertwig, 1906; Tannreuther, 1908; Goetsch, 1922; Hyman, 1928; Loomis, 1954; Zihler, 1972; Sugiyama and Fugisawa, 1977a; Martin et al., 1997; Nishimiya-Fujisawa and Kobayashi, 2012); tissue induction and organizing activity (Browne, 1909; Yao, 1945; MacWilliams, 1983a, b; Lenhoff, 1991; Broun and Bode, 2002; Bode, 2012); regeneration from reaggregated cells (Child, 1928; Noda, 1971; Gierer et al., 1972; Murate et al., 1997; Technau et al., 2000); the paradigmatic value of i-cell free (i.e. epithelial) Hydra (Diehl and Burnett, 1964; Campbell, 1976; Sugiyama and Fujisawa, 1978a); genetic analyses of developmental mechanisms (Sugiyama and Fujisawa, 1977a, b; Marcum and Campbell, 1978; Sugiyama and Fujisawa, 1978a, b; Shimizu, 2012); modeling of patterning (Turing, 1952; Wolpert, 1969; Gierer and Meinhardt, 1972; Wolpert et al., 1972; Gierer, 2012; Meinhardt, 2012); stem cells and stemness (David and Murphy, 1977; David and Plotnick, 1980; Bosch and David, 1987; Bode, 1996; Millane et al., 2011; David, 2012; Hemmrich et al., in press; Hobmayer et al., 2012; Plickert et al., 2012); nematocyte differentiation (David and Gierer, 1974; Campbell and Marcum, 1980; Fujisawa et al., 1986; Grens et al., 1995; Lindgens et al., 2004; Miljkovic-Licina et al., 2004; Hwang et al., 2007; Galliot et al., 2009); nematocyst structure, content and discharge (Chapman and Tilney, 1959; Holstein and Tardent, 1984; Tardent, 1995; Beckmann and Ozbek, 2012; Plachetzki et al., 2012; Rachamim and Sher, 2012); anatomy and differentiation of the nervous system (Schneider, 1890; Hadzi, 1909; McConnell, 1932; Burnett and Diehl, 1964; David and Gierer, 1974; Berking, 1979; Koizumi and Bode, 1986; Koizumi et al., 1992; Gauchat et al., 1998; Lindgens et al., 2004; Guder et al., 2006; Koizumi, 2007; Miljkovic-Licina et al., 2007; Galliot and Quiquand, 2011); neurophysiology (Loomis, 1955; Lenhoff and Bovaird, 1961; Passano and McCullough, 1962, 1963; Westfall et al., 1971; Kass-Simon and Pierobon, 2007; Pierobon, 2012); aging and stress response (Brien, 1953; Martinez, 1998; Yoshida et al., 2006; Martinez and Bridge, 2012; Quinn, 2012); mesoglea structure and functions (Hess, 1957; Shostak et al., 1965; Sarras et al., 1991,1994; Sarras and Deutzmann, 2001; Shimizu et al., 2002; Sarras, 2012); symbiosis (Haffner, 1925; Muscatine and Lenhoff, 1963; Bossert and Dunn, 1986; Kovacevic, 2012); innate immune system (Bibb and Campbell, 1973; Bosch, 1986; Miller et al., 2007; Altincicek and Vilcinskas, 2008; Bosch et al., 2009; Augustin and Bosch, 2011), peptide signaling and peptidomics (Lentz, 1965; Bodenmuller and Schaller, 1981; Grimmelikhuijzen, 1983; Schaller et al., 1989; Leitz et al., 1994; Hoffmeister, 1996; Takahashi et al., 1997; Grens et al., 1999; Fujisawa, 2008; Fujisawa and Hayakawa, 2012); transcription factors (Schummer et al., 1992; Galliot et al., 1995; Grens et al., 1996; Martinez et al., 1997; Gauchat et al., 1998; Broun et al., 1999; Smith et al., 1999; Technau and Bode, 1999; Gauchat et al., 2000; Gauchat et al., 2004; Lindgens et al., 2004; Miljkovic-Licina et al., 2007; Bridge et al., 2010; Nakamura et al., 2011; Ambrosone et al., 2012; Klingel et al., 2012); cell death signaling (Cikala et al., 1999; Technau et al., 2003; Chera et al., 2006; Chera et al., 2009; Lasi et al., 2010a, b; Chera et al., 2011; Reiter et al., 2012); growth factor signaling (Bosch et al., 1995; Hobmayer et al., 2000; Kaloulis et al., 2004; Philipp et al., 2005; Arvizu et al., 2006; Bosch, 2007; Bottger and Hassel, 2012; Galliot, 2012; Plickert et al., 2012); transgenesis (Wittlieb et al., 2006; Khalturin et al., 2007; Dana et al., 2012) and finally, genomic, transcriptomic and proteomic studies (Hwang et al., 2007; Chapman et al., 2010; Hemmrich et al., in press; Balasubramaniam et al., 2012; Steele, 2012). 
simple and continuous shape, molecular markers as a series of gene expression patterns help visualize boundaries all along the body column of the adult Hydra polyp (Galliot, 2000; Hobmayer et al., 2000; Steele, 2002; Bottger and Hassel, 2012). Secondly, they argue that the formation of these boundaries can easily be monitored during budding, the asexual mode of reproduction preferentially used by Hydra when maintained in favorable conditions, i.e. at room temperature with regular feeding (Hyman, 1928; Brien, 1953; Otto and Campbell, 1977b, a). The budding process consists in the elongation of a new axis perpendicular to the parental one, it takes place in the lower part of the body column and produces a fully developed new Hydra ready to detach from the parent in few days. So far 17 molecular markers of the budding process have been identified and the analysis of their temporal and spatial regulation demonstrates the progressive regionalization of the growing bud, first to define the circular zone on the parent where the bud will form, then to define the bud spot from which the bud will emerge, and progressively the different domains in the growing bud that will get refined during bud maturation. Interestingly these markers point to highly conserved signaling pathways, Wnt, BMP, FGF and Notch. Pharmacological approaches have confirmed the importance of the FGFR/Notch signaling to definitely establish the parent/but boundary as when the FGFR or Notch patways are inhibited, buds develop well but never detach from the parent. Thus Hydra offers here a powerful and easily amenable experimental framework to investigate the intimate mechanisms of boundary formation.

\section{Evolutionary studies in the genomic era}

In 2010 the genome of Hydra magnipapillata was made available (Chapman et al., 2010) and in this issue Rob Steele asks three questions to clarify the content of these genomic sequences: What genes are present? What genes are absent? What genes are novel? (Steele, 2012). Basically all signaling pathways active in developing bilaterians can be found in the Hydra genome as anticipated from previous studies. In some cases the gene families even show an astonishing diversification. For example with respect to the Wnt signaling molecules, Hydraexpresses 9 Wnt orthologs out of the 13 gene families found in bilaterians, when humans express 12 of them, Anopheles 6, Drosophila 5 and C. elegans a single one (Lengfeld et al., 2009). This analysis (and others) prove that ecdysozoans have lost a significant number of gene families that are conserved from cnidarians to vertebrates. Rob Steele also tells us what is missing in Hydra; transcription factors as Emx or Evx although present in other hydrozoan species, pluripotency regulators as Nanog and Klf4 that appear to be vertebrate innovations, and more surprisingly peptides previously characterized in Hydra either biochemically as Head Activator (Schaller \& Bodenmueller, 1981) or molecularly as Heady (Lohmann and Bosch, 2000), both involved in apical patterning and bud formation. The lack of genes coding for short peptides might reflect the incomplete assembly of the genome or alternative biosynthetic pathways. Finally, this review proposes to visit some interesting perspectives that genomics and transcriptomics, combined with transgenic strategies make possible.

\section{Peptide signaling in Hydra}

First evidences for a putative signaling function of peptides in Hydra biology came in the early 1960s when efforts were made to extract from Hydra tissues substances that show a graded distribution along the body axis and would be able to affect head pattern- ing. In addition, one expected such substances to be produced by nerve cells, as Lentz had shown that neurosecretory granules can induce the formation of multiple heads (Lentz, 1965). Proteasesensitive substances, whose activity was quantified by the number of tentacles regenerated per head, were indeed isolated and shown to localize in nerve membranes (Lesh and Burnett, 1964, 1966; Schaller and Gierer, 1973; Schaller, 1973). This Head Activator factor was shown to be active at very low concentration, thus ruling out possible unspecific contaminants as toxins from nematocysts (Muller and Spindler, 1971). Once purified in parallel from Hydra, sea anemone, human hypothalamus, rat hypothalamus, bovine intestine this $11 \mathrm{mer}$ peptide surprisingly showed an identical sequence highlighting for the first time the conservation of signaling molecules form cnidarians to mammals (Bodenmuller and Schaller, 1981; Schaller and Bodenmuller, 1981). Head Activator was then used in a number of studies by different groups and it turned out that, depending on its concentration, it can promote cell proliferation and neuronal differentiation, enhancing thus head regeneration and budding (Schaller et al., 1989; Schaller et al., 1996). As discussed by Rob Steele the corresponding gene could not be identified in the genome sequences (Steele, 2012). In parallel efforts, peptides promoting foot differentiation were purified by Sabine Hoffmeister, confirmed this time by gene cloning (Hoffmeister, 1996; Grens et al., 1999; Hoffmeister-Ullerich, 2007).

But peptides are not only active as morphogens as several classes of peptides actually perform neurophysiological tasks, and for a while neurotransmission was even assumed to be predominantly peptidergic in cnidarians (Grimmelikhuijzen et al., 2002; Pierobon, 2012). In the 1990s an ambitious screen for Hydra peptides was launched in Japan, identifying both neuropeptides and epitheliopeptides (Takahashi et al., 1997). In this issue, Toshitaka Fujisawa and Eisuke Hayakawa report about the signaling pathways activated by these peptides, most frequently through G-protein coupled receptors. They also discuss the highly variable evolutionary constraints applied on these peptide gene families, either conserved across eumetazoan phyla, or taxon-restricted, performing phylum- or even species-specific functions (Fujisawa and Hayakawa, 2012). Thus peptide analysis provides a tool to understand the evolution of Hydra-specific traits.

\section{Hydra - a model system for neurophysiology}

Hydra provides a model system for neurophysiological studies since the first description by Abraham Trembley of their active feeding behavior, immobilizing their food with their tentacles and ingesting it in a co-ordinated fashion in their mouth. 150 years later Jovan Hadzi described for the first time their neuroanatomy, sensory nerve cells connected to a loose neuronal network - nerve net- (Hadzi, 1909) and some years later Carl McConnell observed the development of the ectodermal nerve net when the animals differentiate their head (McConnell, 1932). Subsequently the feeding response was the topic of much attention and the fact that animals can feed on live animals but not on dead ones suggested that they received from their preys some signals necessary to initiate the feeding response (Beutler, 1924). Helen Park observed that reduced glutathione (GSH) induces a prolonged mouth opening and William Loomis and Howard Lenhoff proposed that GSH be the signal regulating the feeding behavior (Loomis, 1955; Lenhoff and Bovaird, 1961). However GSH might not be the only active substance (Forrest, 1962). Nevertheless GSH was subsequently 
used as an exogenous stimulant to investigate the mechanisms of the feeding response independently of the nematocyst discharge. In parallel neurophysiologists identified the pacemakers that control behaviors in Hydraand characterized polarized synapses (Passano and McCullough, 1963; Westfall et al., 1971).

More recent pharmacological and molecular studies have demonstrated the co-existence in cnidarian nervous systems of fast (acetylcholine, glutamate, GABA, glycine) and slow (catecholamines, serotonin) neurotransmitters besides neuropeptides (Kass-Simon and Pierobon, 2007). In this issue, Paola Pierobon proposes a scenario whereby the multipolar GABAergic neurons in the apical region provide an integrative response that regulates the initiation and the termination of the feeding response (Pierobon, 2012).

\section{The nematocyst, a sophisticated organelle with outstanding biomechanical properties}

The nematocysts (or cnidocysts) are highly specialized venomcontaining organelles, basically thick wall capsules equipped with a tubule, which differentiate in the nematocytes (or cnidocytes) and play a role in predation, in defence and in locomotion. Indeed, their discharge is responsible for the immobilisation of the preys, but also for the attachment of the tentacles to the substrate during walking (Ewer, 1947; Tardent, 1995). Since their initial description (Weill, 1934a, b), the study of their biogenesis and their physiology led to surprising discoveries as for example the unique speed of their discharge (Holstein and Tardent, 1984) or the negative regulation of their discharge by opsins (Plachetzki et al., 2012). In this issue Anna Beckmann and Suat Ozbek recapitulate what is currently known about their structural composition to provide these outstanding biomechanical properties. Interestingly they show that numerous constituants are actually found in the extra-cellular matrix (ECM) as collagens, lectins, glysominoglycans, as confirmed by the proteome analysis (Balasubramanian et al., 2012). They propose that to store safely soluble toxins, cells chose to import intracellularly ECM components (Beckmann and Ozbek, 2012).

\section{The importance of the extra-cellular matrix (ECM) in devel- opmental processes}

The ECM in Hydra is a porous collagenous layer that maintains together the two epithelial cell layers, providing thus the shape but also the resistance and the flexibility of the animal (Sarras and Deutzmann, 2001; Shimizu et al., 2008). The questions raised by Michael Sarras in this issue are centered on two main issues: what are the biochemical properties that provide this unusual flexible and elastic structure, and what function(s) is playing the ECM on the amazing developmental potential of Hydra (Sarras, 2012). For the first question, he shows that the structure of the ECM is both conserved, sharing common structural elements with vertebrates as the laminin - collagen type IV polymerized network to provide the basal plasma membrane border of each epithelial layer (possibly interacting with epithelial cells through integrins), but also derived as the Hydra collagen type IV proteins, that show a quite distinct homotrimeric organization, much more flexible than the vertebrate collagen type IV. Similarly the major triple helical domain of the fibrillar collagen 1 has the same length in Hydra and in vertebrates but again the supramolecular organization is quite different with the Hydra Hcol-1 forming fine fibrils and the vertebrate collagen 1 rather forming banded fibrils.

Concerning the functions of the ECM, it was tested with multiple approaches (pharmacological, blocking antibodies, gene silencing via antisense RNA or insertion of exogenous ECM) in a variety of contexts, especially during reaggregation from dissociated tissues when the two epithelial cell layers come into contact in the absence of any ECM (Kishimoto et al., 1996; Murate et al., 1997), but also during regeneration and budding (Aufschnaiter et al., 2011). It turned out that the ECM plays an essential role for all these processes that are blocked when the ECM cannot form properly (see in Sarras, 2012). At the cellular level the ECM is required for cell proliferation, cell migration, cell differentiation, cell transdifferentiation. Future steps will then be to understand the bidirectional signaling that regulates the interactions between the epithelial cell layers and the ECM.

\section{The homeostatic and developmental functions of cell death}

Cell death occurs in multiple contexts in Hydra, first recognized in animals exposed to colchicine (Campbell, 1976), then in animals of the thermo-sensitive strain sf-1 submitted to heat-shock (Marcum et al., 1980), also in animals submitted to starvation (Bosch and David, 1984), to wounding (Fujisawa and David, 1984), to hetero-grafting (Bosch, 1986), or undergoing oogenesis (Honegger et al., 1989), spermatogenesis (Kuznetsov et al., 2001), massive autophagy (Chera et al., 2006) and finally in head-regenerating tips after mid-gastric bisection (Chera et al., 2009). In the meanwhile, parallel studies showed that the molecular cell death machinery is highly conserved from Hydra to bilaterians (Cikala et al., 1999; Lasi et al., 2010a, b). In addition, a number of cellular and biochemical tools are now available to characterize and quantify cell death in Hydra (Lasi et al., 2010b; Reiter et al., 2012). As discussed by Reiter et al. in this issue, Hydra offers a unique model system to dissect the multiple regulation and functions of cell death in an adult organism; that is, to maintain homeostasis in the absence of nutrients, to react to stress and injury, to insure stem cell renewal and germ cell production, to participate in immune responses (Reiter et al., 2012).

\section{Ecotoxicology and Environment}

Hydra, a model system for aquatic ecotoxicological studies Hydra is not only a model system for cell and developmental biology, but thanks to multiple endpoints that can be monitored (i.e. the morphology, the attachment, the feeding response, the growth rate, the regenerative response), Hydra is also a highly suitable model system for aquatic ecotoxicological studies. Hydra are highly sensitive to heavy metals (cadmium, zinc, copper, uranium, magnesium), possibly because they lack the metal-binding protein metallothionein. However Brian Quinn, François Gagné and Christian Blaise tell us that very little is known about the mechanisms that underlie this toxicity (Quinn et al., 2012). One possibility they discuss is to perform comparative analyses between Hydraspecies that show highly different levels of thermo tolerance as there is a cross protection between thermo tolerance and metal tolerance. Hydra oligactis that displays a reduced stability of hsp70 possibly explaining their lower thermo tolerance (Brennecke et al., 1998), would provide a well-suited framework to test tolerance to metals. But Hydra are also highly sensitive to endocrine disrupting compounds as bisphenol $A$, as evidenced by the rapid alterations of the tentacle morphology or the sexual reproduction. Hydra are good candidates to be tested to organophosphorus pesticides or 
to drugs frequently present in municipal effluents as carbamazepine by looking at the cellular stress responses, at the oxidative stress. By contrast they exhibit a rather low sensitivity to organic toxicants (polychlorinated biphenyls, 4-chlorophenol, lindane, mirex,..). With the exception of organic toxicants, Hydra appears as one of the most sensitive species to toxicants when compared to other invertebrate test organisms, especially for sub-lethal effects. Moreover the use of symbiotic versus aposymbiotic animals can provide useful conditions for investigating the mechanisms of a detected toxicity.

\section{Value of the Hydra model system for studying endosymbiosis}

Unicellular dinoflagellate algae frequently inhabit aquatic invertebrates establishing with their host a mutualistic partnership named symbiosis. Among cnidarians the importance of endosymbiosis is well-established in reef-building corals (Weis and Allemand, 2009). However, endosymbiosis is not restricted to stony corals in cnidarians, it is also present in some sea anemones, jellyfish and Hydra species (see in Venn et al., 2008). Out of the four Hydra species (Kawaida et al., 2010; Martinez etal., 2010), only Hydra viridissima shows endosymbiosis with photosynthetic Chlorella algae living in the endodermal epithelial cells, and transmitted to the oocyte when the animals undergo sexual differentiation (Muscatine and Lenhoff, 1963; Rahat and Reich, 1985). More than 100 years ago Whitney found a way to eliminate these algae without compromising the survival of their host, which then become aposymbiotic (Whitney, 1907). As Hydra can be easily mass cultured in the laboratory, this procedure opened the way to study the complex interactions between the host and the symbionts and design strategies to identify the signals that allow the symbionts to invade the host and avoid its immunological response (Muscatine and Lenhoff, 1965). In this issue Goran Kovacevic recapitulates the current knowledge about the cellular and metabolic processes linked to endosymbiosis in Hydra and discusses the impact of gene flow between symbionts and Hydra (Kovacevic, 2012).

\section{The chemical arsenal and the chemical landscape of Hydra}

In this issue Tamar Rachamim and Daniel Sher discuss the impact of Hydra on its environment, first considering the venom they produce in their nematocysts, but also taking into account all the bioactive compounds they release (Rachamim and Sher, 2012). The venom is supposed to be a complex mix up of toxic as well as non-toxic molecules that all together are responsible for the toxicity of a given venom. In case of Hydra the knowledge concerning the composition of the venom is currently quite vague and partial, although some components were characterized as some cytolytic actinoporins, some ShK domain proteins that block the K+ channels or the neurotoxic phospholipase A2 protein. All these toxic proteins are supposed to have diverged from non-toxic proteins, representing thus convergent evolutionary events between different venomous species. Moreover the composition of the venom is likely different between the different types of nematocysts, either involved in the feeding response (stenoteles, desmonemes), or in defence (holotrichous isorhizae) or in locomotion (atrichous isorhizae) (Ewer, 1947). Therefore further studies should be performed on purified homogenous populations of nematocysts.

As mentioned above, the chemical arsenal in Hydra extends outside nematocytes with bioactive compounds showing tissue or cell-type restricted expression, as the antimicrobial peptide
Periculin $1 A$ expressed exclusively in the female germline (Fraune et al., 2010), the paralytic and pore-forming Hydralysin genes expressed in the digestive cells (Sher et al., 2008), the MAC-PF genes encoding pore-forming domain proteins expressed in gland cells (Miller et al., 2007) or in the peduncle region (Amimoto et al., 2006). Tamar Rachamim and Daniel Sher proposes that together with the discharged venom, the overlap of these domains of expression create "chemical landscapes" along the Hydra body that can be sensed by the neighboring polyps when Hydra live in groups, or by the preys, or by any organism present in the surroundings. Hence Hydra might provide an experimental model to understand how bioactive compounds affect the aquatic biosystem.

\section{Pedagogy}

\section{Hydra - a model system for teaching science}

The last review of this issue focuses on the pedagogical value of the Hydra model system, initially demonstrated by Abraham Trembley who performed his experimental research with the two young children of Count Bentick. This review takes advantage of the unique expertise of Patricia Bossert in this matter, who, as a high school teacher and pedagogical consultant, continuously used the Hydra model system to teach biology in high school classes of New York State over the past 30 years (Bossert and Galliot, 2012). Together with dedicated students she developed a panel of tools and strategies to investigate a variety of biological questions that touch ecology, selection in evolution, photobiology, developmental biology and molecular biology. Each of the teaching units proposed in this article is designed to provide the basic protocols of precise experiments with expected results but also to challenge the students to go further and design their own experiments. Thus, we expect that thanks to the Hydra model system, teachers and young students will develop their curiosity, their creativity and their rationale thinking.

\section{Perspectives}

In the field of cell biology, some key questions remain unanswered. One of them is the degree of cell plasticity that can be observed in Hydra: these animals regenerate in the absence of cell proliferation or in the total absence of nervous system. Does it mean that cell proliferation and nerve cells are not used when the animals are fully equipped or does it instead mean that the animals reprogram when one of their attributes is missing? The second proposition would permit reconciliation of sets of data that at the moment appear contradictory, as for example the role of substances produced by the nerve cells that were shown to promote head formation and participate in morphogenetic processes. A better understanding of the limits and regulation of this plasticity is a major task for the coming years.

Similarly in the field of developmental biology regeneration is often considered as a simple reinterpretation or translation of the homeostatic parameters with no specific regenerative program. However, one can also consider that the reactivation step in the developmental program is in itself specific to regeneration and not simply derived from the homeostatic condition that precedes injury. A series of data actually suggest that this reactivation step is drastically constrained by the homeostatic context as evidenced by the studies that show significant differences between the early stages of head regeneration after decapitation (which is used as 
the reference situation in numerous studies) or after mid-gastric bisection. Again Hydra provides a highly suited system to study the impact of the homeostatic context on the way to launch a regenerative program, a major question to solve before establishing regenerative strategies.

The aim of this issue was primarily to demonstrate to scientists and teachers at any stage of their career that the Hydra model system is fruitful, promising and potent. Potent because this model combines the simplicity of its anatomy to a sound basis of knowledge of the developmental and cellular processes; fruitful because the biological questions that can be addressed with the Hydra model system are multiple and become more and more diverse with time, and finally promising because this system now provides functional tools that can be associated to genomic, transcriptomic and proteomic approaches. Gene knockdown through RNA interference was first established by electroporation, a rather harmful procedure (Lohmann and Bosch, 2000). Later feeding animals with dsRNAs proved to be a relatively easy, incremental and highly efficient procedure when controled at the RNA and protein levels, producing a variety of well characterized phenotypes (Chera et al., 2006, Miljkovic-Licina et al., 2007, Chera et al., 2009; Chera et al., 2011). However the stability of its efficiency in the various Hydra strains/species seems to be affected by infectious agents that compete for the components of the RNAi machinery (BG, unpublished). Therefore additional efforts need to be done to characterize the agents interfering with the RNAi machinery in Hydra. To finish I would say that Hydra are simply esthetic and this is a great pleasure to see them everyday.

\section{Acknowledgements}

The author thanks Patricia Bossert for critical reading of the manuscript. Work on Hydra in my laboratory is supported by the Canton of Geneva, the Swiss National Science Foundation, the National Center of Competence in Research (NCCR) "Frontiers in Genetics", the Human Frontier Science Program (HFSP), the Claraz Donation.

\section{References}

ALTINCICEK, B., VILCINSKAS, A. (2008). Comparative analysis of septic injuryinducible genes in phylogenetically distant model organisms of regeneration and stem cell research, the planarian schmidtea mediterranea and the cnidarian hydra vulgaris. Front Zool 5: 6.

AMBROSONE, A., MARCHESANO, V., TINO, A., HOBMAYER, B., TORTIGLIONE, C. (2012). Hymyc1 downregulation promotes stem cell proliferation in Hydra vulgaris. PLOS ONE 7: e30660.

AMIMOTO, Y., KODAMA, R., KOBAYAKAWA, Y. (2006). Foot formation in Hydra: a novel gene, anklet, is involved in basal disk formation. Mech Dev 123: 352-361.

ARVIZU, F., AGUILERA, A., SALGADO, L.M. (2006). Activities of the protein kinases STK, PI3K, MEK, and ERK are required for the development of the head organizer in Hydra magnipapillata. Differentiation 74: 305-312.

AUGUSTIN, R., BOSCH, T.C. (2011). Cnidarian immunity: A tale of two barriers. Adv Exp Med Biol 708: 1-16.

AUFSCHNAITER, R., ZAMIR, E.A., LITTLE, C.D., OZBEK, S., MUNDER, S., DAVID, C.N., LI, L., SARRAS, M.P., JR., ZHANG, X. (2011). In vivo imaging of basement membrane movement: ECM patterning shapes Hydra polyps. J Cell Sci 124: 4027-4038.

BALASUBRAMANIAN, P.G., BECKMANN, A., WARNKEN, U., SCHNOLZER, M., SCHULER, A., BORNBERG-BAUER, E., HOLSTEIN, T.W., OZBEK, S. (2012). Proteome of Hydra nematocyst. J Biol Chem 287: 9672-9681.

BECKMANN, A., OZBEK, S. (2012). The Nematocyst: A molecular map of the cnidarian stinging organelle. Int J Dev Biol 56: 577-582.

BERKING, S. (1979). Control of nerve cell formation from multipotent stem cells in hydra. J Cell Sci 40: 193-205.

BEUTLER, R. (1924). Experimentelle Untersuchungen über die Verdauug bei hydra. Zeitschr vergleich Physiol 1: 1-56.

BIBB, C., CAMPBELL, R.D. (1973). Cell affinity determining heterospecific graft intolerance in hydra. Tissue Cell 5: 199-208.

BODE, H.R. (1996). The interstitial cell lineage of hydra: a stem cell system that arose early in evolution. J Cell Sci 109 (Pt 6): 1155-1164.

BODE, H.R. (2012). The head organizer in Hydra. Int J Dev Biol 56: 473-478.

BODE, H.R., HEIMFELD, S., CHOW, M.A., HUANG, L.W. (1987). Gland cells arise by differentiation from interstitial cells in Hydra attenuata. Dev Biol 122: 577-585.

BODENMULLER, H., SCHALLER, H.C. (1981). Conserved amino acid sequence of a neuropeptide, the head activator, from coelenterates to humans. Nature 293: $579-580$

BOSCH, T.C. (1986). Immunocompetence in Hydra: epithelial cells recognize selfnonself and react against it. J Exp Zool 238: 225-234.

$\mathrm{BOSCH}$, T.C. (2007). Why polyps regenerate and we don't: towards a cellular and molecular framework for Hydra regeneration. Dev Biol 303: 421-433.

BOSCH, T.C., AUGUSTIN, R., ANTON-ERXLEBEN, F., FRAUNE, S., HEMMRICH, G., ZILL, H., ROSENSTIEL, P., JACOBS, G., SCHREIBER, S., LEIPPE, M. et al. (2009). Uncovering the evolutionary history of innate immunity: The simple metazoan hydra uses epithelial cells for host defence. Dev Comp Immunol 33:559-569.

BOSCH, T.C., BENITEZ, E., GELLNER, K., PRAETZEL, G., SALGADO, L.M. (1995), Cloning of a ras-related gene from Hydra which responds to head-specific signals. Gene 167: 191-195.

BOSCH, T.C., DAVID, C.N. (1984). Growth regulation in Hydra: relationship between epithelial cell cycle length and growth rate. Dev Biol 104: 161-171.

BOSCH, T.C.G., DAVID, C.N. (1987). Stem cells of hydra manipapillata can differentiate into somatic cells and germ line cells. Dev Biol 121: 182-191.

BOSSERT, P., DUNN, K.W. (1986). Regulation of intracellular algae by various strains of the symbiotic Hydra viridissima. J Cell Sci 85: 187-195.

BOSSERT, P., and GALLIOT, B. (2012). How to use Hydra as a model system to teach biology in a classroom? Int J Dev Biol 56: 637-652.

BÖTTGER, A. and HASSEL, M. (2012). Hydra, a model system to trace the emergence of boundaries in eumetazoans. Int J Dev Biol 56: 583-591.

BRAUER, A. (1891). Ueber die Entwicklung von Hydra. Zschr Wiss Zool52: 169-216.

BRENNECKE, T., GELLNER, K., BOSCH, T.C. (1998). The lack of a stress response in Hydra oligactis is due to reduced hsp70 mRNA stability. Eur J Biochem 255: 703-709.

BRIDGE, D., THEOFILES, A.G., HOLLER, R.L., MARCINKEVICIUS, E., STEELE, R.E., MARTINEZ, D.E. (2010). FoxO and stress responses in the cnidarian Hydra vulgaris. PLOS ONE 5: e11686.

BRIEN, P. (1953). La pérennité somatique. Biol. Rev. 28: 308-349.

BRIEN, P., RENIERS-DECOEN, M. (1955). La signification des cellules interstitielles des hydres d'eau douce et le probleme de la réserve embryonnaire. Bull biol $\mathrm{Fr}$ Belg 89: 258-325.

BROUN, M., BODE, H.R. (2002). Characterization of the head organizer in hydra. Development 129: 875-884.

BROUN, M., GEE, L., REINHARDT, B., BODE, H.R. (2005). Formation of the head organizer in hydra involves the canonical Wnt pathway. Development 132: 2907-2916.

BROUN, M., SOKOL, S., BODE, H.R. (1999). Cngsc, a homologue of goosecoid, participates in the patterning of the head, and is expressed in the organizer region of Hydra. Development 126: 5245-5254.

BROWNE, E.N. (1909). The production of new hydranths in hydra by the insertion of small grafts. J Exp Zool 7: 1-37.

BURNETT, A.L., DIEHL, N.A. (1964). The Nervous System of Hydra. I. Types, Distribution and Origin of Nerve Elements. J Exp Zool 157: 217-226.

CAMPBELL, R.D. (1976). Elimination by Hydra interstitial and nerve cells by means of colchicine. J Cell Sci 21: 1-13.

CAMPBELL, R.D., MARCUM, B.A. (1980). Nematocyte migration in hydra: evidence for contact guidance in vivo. $J$ Cell Sci 41: 33-51.

CHAPMAN, G.B., TILNEY, L.G. (1959). Cytological studies of the nematocysts of Hydra. II. The stenoteles. J Biophys Biochem Cytol 5: 79-84.

CHAPMAN, J.A., KIRKNESS, E.F., SIMAKOV, O., HAMPSON, S.E., MITROS, T., 
WEINMAIER, T., RATTEI, T., BALASUBRAMANIAN, P.G., BORMAN, J., BUSAM, D. et al. (2010). The dynamic genome of Hydra. Nature 464: 592-596.

CHERA, S., DE ROSA, R., MILJKOVIC-LICINA, M., DOBRETZ, K., GHILA, L., KALOULIS, K., GALLIOT, B. (2006). Silencing of the hydra serine protease inhibitor Kazal1 gene mimics the human SPINK1 pancreatic phenotype. J Cell Sci 119: 846-857.

CHERA, S., GHILA, L., DOBRETZ, K., WENGER, Y., BAUER, C., BUZGARIU, W., MARTINOU, J.C., GALLIOT, B. (2009). Apoptotic cells provide an unexpected source of Wnt3 signaling to drive hydra head regeneration. Dev Cell 17: 279-289.

CHERA, S., GHILA, L., WENGER, Y., GALLIOT, B. (2011). Injury-induced activation of the MAPK/CREB pathway triggers apoptosis-induced compensatory proliferation in hydra head regeneration. Dev Growth Differ 53: 186-201.

CHILD, C.M. (1928). Axial development in aggregates of dissociated cells from Corymorpha palma. Phys. Zool. 1: 419-461.

CHILD, C.M. (1932). Determination of New Axes by Lateral Grafts and Incisions in Corymorpha in Relation to the Gradient and Dominance. Phys Zool 5: 593-627.

CIKALA, M., WILM, B., HOBMAYER, E., BOTTGER, A., DAVID, C.N. (1999). Identification of caspases and apoptosis in the simple metazoan Hydra. Curr Biol9: 959-962.

COLLINS, A.G., SCHUCHERT, P., MARQUES, A.C., JANKOWSKI, T., MEDINA, M., SCHIERWATER, B. (2006). Medusozoan phylogeny and character evolution clarified by new large and small subunit rDNA data and an assessment of the utility of phylogenetic mixture models. Syst Biol 55: 97-115.

DANA, C.E., GLAUBER, K.M., CHAN, T.A., BRIDGE, D.M., STEELE, R.E. (2012). Incorporation of a horizontally transferred gene into an operon during cnidarian evolution. PLoS ONE 7: e31643.

DAVID, C.N. (2012). Interstitial stem cells in Hydra: multipotency and decision-making. Int J Dev Biol 56: 489-497.

DAVID, C.N., GIERER, A. (1974). Cell cycle kinetics and development of Hydra attenuata. III. Nerve and nematocyte differentiation. J Cell Sci 16: 359-375.

DAVID, C.N., MURPHY, S. (1977). Characterization of interstitial stem cells in hydra by cloning. Dev Biol 58: 372-383.

DAVID, C.N., PLOTNICK, I. (1980). Distribution of interstitial stem cells in Hydra. Dev Biol 76: 175-184

DIEHL, F.A., BURNETT, A.L. (1964). The Role of Interstitial Cells in the Maintenance of Hydra. I. Specific Destruction of Interstitial Cells in Normal, Asexual, Non-Budding Animals. J Exp Zool 155: 253-259.

EWER, R.F. (1947). On the functions and mode of action of the nematocysts of Hydra. Proc Zool Soc Lond 117: 365-376.

FORREST, H. (1962). Lack of dependence of the feeding reaction in Hydra on reduced glutathione. Biol Bull 122: 343-361.

FRANK, U., LEITZ, T., MULLER, W.A. (2001). The hydroid Hydractinia: a versatile, informative cnidarian representative. BioEssays 23: 963-971.

FRAUNE, S., AUGUSTIN, R., ANTON-ERXLEBEN, F., WITTLIEB, J., GELHAUS, C., KLIMOVICH, V.B., SAMOILOVICH, M.P., BOSCH, T.C. (2010). In an early branching metazoan, bacterial colonization of the embryo is controlled by maternal antimicrobial peptides. Proc Natl Acad Sci USA 107: 18067-18072.

FUJISAWA, T. (2008). Hydra peptide project 1993-2007. Dev Growth Differ 50: S257-S268.

FUJISAWA, T., DAVID, C.N. (1984). Loss of differentiating nematocytes induced by regeneration and wound healing in Hydra. J Cell Sci 68: 243-255.

FUJISAWA, T. and HAYAKAWA, E. (2012). Peptide signaling in Hydra. Int J Dev Biol 56: 543-550.

FUJISAWA, T., NISHIMIYA, C., SUGIYAMA, T. (1986). Nematocyte differentiation in hydra. Curr Top Dev Biol 20: 281-290.

GALLIOT, B. (2000). Conserved and divergent genes in apex and axis development of cnidarians. Curr Opin Genet Dev 10: 629-637.

GALLIOT, B. (2012). Injury-induced asymmetric cell death as a driving force for head regeneration in Hydra. Dev Genes Evol in press.

GALLIOT, B., QUIQUAND, M. (2011). A two-step process in the emergence of neurogenesis. Eur J Neurosci 34: 847-862.

GALLIOT, B., QUIQUAND, M., GHILA, L., DE ROSA, R., MILJKOVIC-LICINA, M., CHERA, S. (2009). Origins of neurogenesis, a cnidarian view. Dev Bio/332: 2-24.

GALLIOT, B., SCHMID, V. (2002). Cnidarians as a model system for understanding evolution and regeneration. Int J Dev Biol 46: 39-48.
GALLIOT, B., WELSCHOF, M., SCHUCKERT, O., HOFFMEISTER, S., SCHALLER, H.C. (1995). The cAMP response element binding protein is involved in hydra regeneration. Development 121: 1205-1216.

GAUCHAT, D., ESCRIVA, H., MILJKOVIC-LICINA, M., CHERA, S., LANGLOIS, M.C., BEGUE, A., LAUDET, V., GALLIOT, B. (2004). The orphan COUP-TF nuclear receptors are markers for neurogenesis from cnidarians to vertebrates. Dev Biol 275: 104-123.

GAUCHAT, D., KREGER, S., HOLSTEIN, T., GALLIOT, B. (1998). prdl-a, a gene marker for hydra apical differentiation related to triploblastic paired-like headspecific genes. Development 125: 1637-1645.

GAUCHAT, D., MAZET, F., BERNEY, C., SCHUMMER, M., KREGER, S., PAWLOWSKI, J., GALLIOT, B. (2000). Evolution of Antp-class genes and differential expression of Hydra Hox/paraHox genes in anterior patterning. Proc Natl Acad Sci USA 97: 4493-4498.

GEE, L., HARTIG, J., LAW, L., WITTLIEB, J., KHALTURIN, K., BOSCH, T.C., BODE, H.R. (2010). beta-catenin plays a central role in setting up the head organizer in hydra. Dev Biol 340: 116-124.

GIERER, A. (2012). The Hydra model - a model for what? Int J Dev Biol 56: 437-445.

GIERER, A., BERKING, S., BODE, H., DAVID, C.N., FLICK, K., HANSMANN, G., SCHALLER, H., TRENKNER, E. (1972). Regeneration of hydra from reaggregated cells. Nat New Biol 239: 98-101.

GIERER, A., MEINHARDT, H. (1972). A theory of biological pattern formation. Ky bernetik 12: 30-39.

GOETSCH, W. (1922). Gonochorismus und hermaphroditismus bei hydrozoen. Zool Anz 55: 30-34.

GREENWOOD, M. (1888). On Digestion in Hydra, with some Observations on the Structure of the Endoderm. J. Physiol. 9: 317-i316.

GRENS, A., GEE, L., FISHER, D.A., BODE, H.R. (1996). CnNK-2, an NK-2 homeobox gene, has a role in patterning the basal end of the axis in hydra. Dev Biol 180: 473-488.

GRENS, A., MASON, E., MARSH, J.L., BODE, H.R. (1995). Evolutionary conservation of a cell fate specification gene: the Hydra achaete-scute homolog has proneural activity in Drosophila. Development 121: 4027-4035.

GRENS, A., SHIMIZU, H., HOFFMEISTER, S.A., BODE, H.R., FUJISAWA, T. (1999). The novel signal peptides, pedibin and Hym-346, lower positional value thereby enhancing foot formation in hydra. Development 126: 517-524.

GRIMMELIKHUIJZEN, C.J. (1983). Coexistence of neuropeptides in hydra. Neuroscience 9: 837-845.

GRIMMELIKHUIJZEN, C.J., WILLIAMSON, M., HANSEN, G.N. (2002). Neuropeptides in cnidarians. Can J Zool 80: 1690-1702.

GUDER, C., PINHO, S., NACAK, T.G., SCHMIDT, H.A., HOBMAYER, B., NIEHRS, C., HOLSTEIN, T.W. (2006). An ancient wnt-dickkopf antagonism in hydra. Development 133: 901-911.

HADZI, H. (1909). Über das Nervensystem von Hydra. Arb Zool Inst Univ Wein 17 225-268.

HAECKEL, E. (1896). Systematische Phylogenie der Wirbellosen Thiere. Reimer, Berlin.

HAFFNER, K. (1925). Untersuchungen über die symbiose von dalyellia viridis und chiorohydra viridissima mit chlorellen. Zeitschrift für wissenschaftiche Zoo!ogie 126: 1-69.

HEMMRICH, G., KHALTURIN, K., BOEHM, A.M., PUCHERT, M., ANTON-ERXLEBEN, F., WITTLIEB, J., KLOSTERMEIER, U.C., ROSENSTIEL, P., OBERG, H.H., DOMAZET-LOSO, T. et al. (in press). Molecular signatures of the three stem cell lineages in Hydra and the emergence of stem cell function at the base of multicellularity. Mol Biol Evol. DOI: 10.1093/molbev/mss134

HERTWIG, R. (1906). Ueber Knospung und Geschlechtentwicklung von Hydra fusca. Biol Zbl 26: 489-508.

HESS, A. (1957). Observations on the structure of Hydra as seen with the electron and light microscope. Quart J micro Sci 98: 315-326.

HOBMAYER, B., JENEWEIN, M., EDER, D., GLASAUER, S., GUFLER, S., HARTL, M. and SALVENMOSER, W. (2012). Stemness in Hydra - a current perspective. Int J Dev Biol 56: 509-517.

HOBMAYER, B., RENTZSCH, F., KUHN, K., HAPPEL, C.M., VON LAUE, C.C., SNYDER, P., ROTHBACHER, U., HOLSTEIN, T.W. (2000). WNT signalling molecules act in axis formation in the diploblastic metazoan Hydra. Nature 407: 186-189. 
HOFFMEISTER, S.A. (1996). Isolation and characterization of two new morphogenetically active peptides from Hydra vulgaris. Development 122: 1941-1948.

HOFFMEISTER-ULLERICH, S.A. (2007). Hydra--ancient model with modern outfit. Cell Mol Life Sci 64: 3012-3016.

HOLSTEIN, T., TARDENT, P. (1984). An ultrahigh-speed analysis of exocytosis: nematocyst discharge. Science 223: 830-833.

HONEGGER, T.G., ZURRER, D., TARDENT, P. (1989). Oogenesis in Hydra carnea: A new model based on light and electron microscopic analyses of oocyte and nurse cell differentiation. Tissue Cell 21: 381-393.

HOULISTON, E., MOMOSE, T., MANUEL, M. (2010). Clytia hemisphaerica: a jellyfish cousin joins the laboratory. Trends Genet 26: 159-167.

HWANG, J.S., OHYANAGI, H., HAYAKAWA, S., OSATO, N., NISHIMIYA-FUJISAWA C., IKEO, K., DAVID, C.N., FUJISAWA, T., GOJOBORI, T. (2007). The evolutionary emergence of cell type-specific genes inferred from the gene expression analysis of Hydra. Proc Natl Acad Sci USA 104: 14735-14740.

HYMAN, L. (1928). Miscellaneous observations with special reference to reproduction. Biol Bull Wood's Hole 54: 65-109.

HYMAN, L.H. (1940). The Invertebrates: I. Protozoa through Ctenophora. McGrawHill, New York.

KALOULIS, K., CHERA, S., HASSEL, M., GAUCHAT, D., GALLIOT, B. (2004) Reactivation of developmental programs: the cAMP-response element-binding protein pathway is involved in hydra head regeneration. Proc Natl Acad Sci USA 101: 2363-2368.

KASS-SIMON, G., PIEROBON, P. (2007). Cnidarian chemical neurotransmission, an updated overview. Comp Biochem Physiol A Mol Integr Physiol 146: 9-25.

KAWAIDA, H., SHIMIZU, H., FUJISAWA, T., TACHIDA, H., KOBAYAKAWA, Y. (2010). Molecular phylogenetic study in genus Hydra. Gene 468: 30-40.

KHALTURIN, K., ANTON-ERXLEBEN, F., MILDE, S., PLOTZ, C., WITTLIEB, J., HEMMRICH, G., BOSCH, T.C. (2007). Transgenic stem cells in Hydra reveal an early evolutionary origin for key elements controlling self-renewal and differentiation. Dev Biol 309: 32-44.

KISHIMOTO, Y., MURATE, M., SUGIYAMA, T. (1996). Hydra regeneration from recombined ectodermal and endodermal tissue. I. Epibolic ectodermal spreading is driven by cell intercalation. J Cell Sci 109 (Pt 4): 763-772.

KLEINENBERG, N. (1872). Hydra - eine anatomisch-entwicklungsgeschichtliche untersuchung. Wilhelm Engelmann, Leipzig.

KLINGEL, S., MORATH, I., STRIETZ, J., MENZEL, K., HOLSTEIN, T.W., GRADL, D. (2012). Subfunctionalization and neofunctionalization of vertebrate Lef/Tcf transcription factors. Dev Biol. 368: 44-53.

KOIZUMI, O. (2007). Nerve ring of the hypostome in hydra: is it an origin of the central nervous system of bilaterian animals? Brain Behav Evol 69: 151-159.

KOIZUMI, O., BODE, H.R. (1986). Plasticity in the nervous system of adult hydra. I. The position-dependent expression of fmrfamide-like immunoreactivity. Dev Biol 116: 407-421.

KOIZUMI, O., ITAZAWA, M., MIZUMOTO, H., MINOBE, S., JAVOIS, L.C., GRIMMELIKHUIJZEN, C.J., BODE, H.R. (1992). Nerve ring of the hypostome in hydra. I. Its structure, development, and maintenance. J Comp Neurol 326: 7-21.

KOVACEVIC, G. (2012). Value of the Hydra model system for studying symbiosis. Int J Dev Biol 56: 627-635.

KUZNETSOV, S., LYANGUZOWA, M., BOSCH, T.C. (2001). Role of epithelial cells and programmed cell death in Hydra spermatogenesis. Zoology (Jena) 104:25-31.

LASI, M., DAVID, C.N., BOTTGER, A. (2010a). Apoptosis in pre-Bilaterians: Hydra as a model. Apoptosis 15: 269-278.

LASI, M., PAULY, B., SCHMIDT, N., CIKALA, M., STIENING, B., KASBAUER, T., ZENNER, G., POPP, T., WAGNER, A., KNAPP, R.T., HUBER, A.H., GRUNERT, M., SODING, J., DAVID, C.N., BOTTGER, A. (2010b). The molecular cell death machinery in the simple cnidarian Hydra includes an expanded caspase family and pro- and anti-apoptotic Bcl-2 proteins. Cell Res 20: 812-825.

LEITZ, T., MORAND, K., MANN, M. (1994). Metamorphosin A: a novel peptide controlling development of the lower metazoan Hydractinia echinata (Coelenterata, Hydrozoa). Dev Biol 163: 440-446.

LENGFELD, T., WATANABE, H., SIMAKOV, O., LINDGENS, D., GEE, L., LAW, L., SCHMIDT, H.A., OZBEK, S., BODE, H., HOLSTEIN, T.W. (2009). Multiple Whts are involved in Hydra organizer formation and regeneration. Dev Bio/330: 186-199.

LENHOFF, H., BOVAIRD, J. (1961). Action of glutamic acid and glutathione analogues on the Hydra glutathione-receptor. Nature 189: 486-487.

LENHOFF, H.M. (1991). Ethel Browne, Hans Spemann, and the Discovery of the Organizer Phenomenon. Biol Bull 181: 72-80.

LENHOFF, S.G., LENHOFF, H.M. (1986). Abraham Trembley. Mémoires, Pour Servir à L'histoire d'un Genre De Polypes d'eau Douce, à Bras en Forme de Cornes, Hydra and the Birth of Experimental Biology-1744. The Boxwood Press, Pacific Grove.

LENTZ, T.L. (1965). Hydra: induction of supernumerary heads by isolated neurosecretory granules. Science 150: 633-635.

LENTZ, T.L. (1966). Fine structure of the epidermis and mesoglea, The Cell Biology of Hydra. North-Holland Publishing Company, Amsterdam, pp. 38-50.

LESH, G.E., BURNETT, A.L. (1964). Some Biological and Biochemical Properties of the Polarizing Factor in Hydra. Nature 204: 492-493.

LESH, G.E., BURNETT, A.L. (1966). An analysis of the chemical control of polarized form in hydra. J Exp Zool 163: 55-77.

LINDGENS, D., HOLSTEIN, T.W., TECHNAU, U. (2004). Hyzic, the Hydra homolog of the zic/odd-paired gene, is involved in the early specification of the sensory nematocytes. Development 131: 191-201.

LINNAEUS, C. (1758). Systema Naturae per regna tria naturae, secundum classes, ordines, genera, species, Editio decima, reformata. ed. Holmiae.

LOHMANN, J.U., BOSCH, T.C. (2000). The novel peptide HEADY specifies apical fate in a simple radially symmetric metazoan. Genes Dev 14: 2771-2777.

LOOMIS, W.F. (1954). Reversible induction of sexual differentiation in Hydra. Science 120: 145-146.

LOOMIS, W.F. (1955). Glutathione control of the specific feeding reactions of hydra. Ann. N. York. Acad. Sci. 62: 209-228.

MACWILLIAMS, H.K. (1983a). Hydra transplantation phenomena and the mechanism of hydra head regeneration. I. Properties of the head inhibition. Dev Bio/96:217-238.

MACWILLIAMS, H.K. (1983b). Hydratransplantation phenomena and the mechanism of Hydra head regeneration. II. Properties of the head activation. Dev Biol96:239-257.

MARCUM, B.A., CAMPBELL, R.D. (1978). Developmental roles of epithelial and interstitial cell lineages in hydra: analysis of chimeras. J Cell Sci 32: 233-247.

MARCUM, B.A., FUJISAWA, T., SUGIYAMA, T. (1980). A mutant hydra strain (sf-1) containing temperature-sensitive interstitial cells. In Developmental and Cellular Biology of Coelenterates. (Eds. P. Tardent and R. Tardent). Elsevier/North Holland, Amsterdam, pp. 429-434.

MARTIN, V.J., LITTLEFIELD, C.L., ARCHER, W.E., BODE, H.R. (1997). Embryogenesis in hydra. Biol Bull 192: 345-363.

MARTINEZ, D.E. (1998). Mortality patterns suggest lack of senescence in hydra Exp Gerontol 33: 217-225.

MARTINEZ, D., BRIDGE, D. (2012). Hydra, the everlasting embryo, confronts aging. Int J Dev Biol 56: 479-487.

MARTINEZ, D.E., DIRKSEN, M.L., BODE, P.M., JAMRICH, M., STEELE, R.E., BODE, H.R. (1997). Budhead, a fork head/HNF-3 homologue, is expressed during axis formation and head specification in hydra. Dev Biol 192: 523-536.

MARTINEZ, D.E., INIGUEZ, A.R., PERCELL, K.M., WILLNER, J.B., SIGNOROVITCH, J., CAMPBELL, R.D. (2010). Phylogeny and biogeography of Hydra (Cnidaria: Hydridae) using mitochondrial and nuclear DNA sequences. Mol Phylogenet Evol 57: 403-410.

MCCONNELL, A. (1990). The flowers of coral - Some unpublished conflicts from Montpellier and Paris during the early 18th century. His. Philos. Life Sci. 12:51-66.

MCCONNELL, C.H. (1932). The development of the ectodermal nerve net in the buds of hydra. Quart J Microsc Sci 75: 495-509.

MEINHARDT, H. (2012) Modeling pattern formation in hydra: a route to understanding essential steps in development. Int. J. Dev. Biol. 56: 447-462.

MILJKOVIC-LICINA, M., CHERA, S., GHILA, L., GALLIOT, B. (2007). Head regeneration in wild-type hydra requires de novo neurogenesis. Development 134: 1191-1201.

MILJKOVIC-LICINA, M., GAUCHAT, D., GALLIOT, B. (2004). Neuronal evolution: analysis of regulatory genes in a first-evolved nervous system, the hydra nervous system. Biosystems 76: 75-87.

MILLANE, R.C., KANSKA, J., DUFFY, D.J., SEOIGHE, C., CUNNINGHAM, S., PLICKERT, G., FRANK, U. (2011). Induced stem cell neoplasia in a cnidarian by ectopic expression of a POU domain transcription factor. Development 138: 2429-2439.

MILLER, D.J., HEMMRICH, G., BALL, E.E., HAYWARD, D.C., KHALTURIN, K. FUNAYAMA, N., AGATA, K., BOSCH, T.C. (2007). The innate immune repertoire 
in cnidaria--ancestral complexity and stochastic gene loss. Genome Biol 8: R59.

MULLER, W.A., SPINDLER, K.D. (1971). The 'polarizing inducer' in Hydra: a reexamination of its properties and its origin. Arch EntwMech Org 167: 325-335.

MURATE, M., KISHIMOTO, Y., SUGIYAMA, T., FUJISAWA, T., TAKAHASHI-IWANAGA, H., IWANAGA, T. (1997). Hydra regeneration from recombined ectodermal and endodermal tissue. II. Differential stability in the ectodermal and endodermal epithelial organization. J Cell Sci 110: 1919-1934.

MUSCATINE, L., LENHOFF, H.M. (1963). Symbiosis: On the Role of Algae Symbiotic with Hydra. Science 142: 956-958.

MUSCATINE, L., LENHOFF, H.M. (1965). Symbiosis of hydra and algae. I. Effects of some environmental cations on growth of symbiotic and aposymbiotic hydra. Biol Bull 128: 415-424.

MUTZ, E. (1930). Transplantationsversuche an Hydra mit besonderer Beriicksichtigung der Induktion, Regionalität, Polarität. Arch EntwMech Org 121: 210-271.

NAKAMURA, Y., TSIAIRIS, C.D., OZBEK, S., HOLSTEIN, T.W. (2011). Autoregulatory and repressive inputs localize Hydra Wnt3 to the head organizer. Proc Natl Acad Sci USA 108: 9137-9142.

NISHIMAYA-FUJISAWA, C. (2012). Germline stem cells and sex determination in Hydra. Int J Dev Biol 56: 499-508.

NODA, K. (1971). Reconstitution of dissociated cells of hydra. Zool Mag 80: 99-101.

OTTO, J.J., CAMPBELL, R.D. (1977a). Budding in Hydra attenuata: bud stages and fate map. J Exp Zool 200: 417-428.

OTTO, J.J., CAMPBELL, R.D. (1977b). Tissue economics of hydra: regulation of cell cycle, animal size and development by controlled feeding rates. J Cell Sci 28: 117-132.

PALM, L.C. (1996). Vol XIV: 21 letters written between August 1701 and March 1704, in The Collected Letters of Antoni van Leeuwenhoek. Swets and Zeitlinger, Leiden, p. 440.

PASSANO, L.M., MCCULLOUGH, C.B. (1962). The Light Response and the Rhythmic Potentials of Hydra. Proc Natl Acad Sci USA 48: 1376-1382.

PASSANO, L.M., MCCULLOUGH, C.B. (1963). Pacemaker Hierarchies Controlling the Behaviour of Hydras. Nature 199: 1174-1175.

PHILIPP, I., HOLSTEIN, T.W., HOBMAYER, B. (2005). HvJNK, a Hydra member of the c-Jun $\mathrm{NH}$-terminal kinase gene family, is expressed during nematocyte differentiation. Gene Expr Patterns 5: 397-402.

PIEROBON, P. (2012). Coordinated modulation of cellular signaling through ligandgated ion channels in Hydra vulgaris (Cnidaria, Hydrozoa). Int J Dev Biol 56: 551-565.

PLACHETZKI, D.C., FONG, C.R., OAKLEY, T.H. (2012). Cnidocyte discharge is regulated by light and opsin-mediated phototransduction. BMC Biol 10: 17.

PLICKERT, G., FRANK, U. and MÜLLER, W. (2012). Hydractinia, a pioneering model for stem cell biology and reprogramming somatic cells to pluripotency. Int J Dev Biol 56: 519-534.

QUINN, B., GAGNE, F., BLAISE, C. (2012). Hydra, a model system for environmental studies. Int J Dev Biol 56: 613-625.

RACHAMIM, T., SHER, D. (2012). What Hydra can teach us about chemical ecology - how a simple, soft organism survives in a hostile aqueous environment. Int J Dev Biol 56: 605-611. RAHAT, M., REICH, V. (1985). Correlations between characteristics of some free-living Chlorella sp. and their ability to form stable symbioses with Hydra viridis. J Cell Sci 74: 257-266.

RAND, H.W. (1899). Regeneration and regulation in Hydra viridis. Archiv Entwick8: 1-34.

RATCLIFF, M.J. (2004). Abraham Trembley's strategy of generosity and the scope of celebrity in the mid-eighteenth century. Isis 95: 555-575.

RATCLIFF, M. (2012). The Trembley Effect or the birth of marine zoology. Int J Dev Biol 56: 425-436

RÉAUMUR, R.A. (1741). Animaux coupés et partagés en plusieurs parties, et qui se reproduisent tout entiers dans chacune. Mémoires de l'Académie Royale des Sciences de Paris 9: 75-76.

REITER, S., GALLIOT, B., BUZGARIU, W. (2012). Hydra, a versatile model to study the homeostatic and developmental functions of cell death. Int J Dev Biol 56: 593-604.

SARRAS, M.P., JR., DEUTZMANN, R. (2001). Hydra and Niccolo Paganini (17821840)--two peas in a pod? The molecular basis of extracellular matrix structure in the invertebrate, Hydra. BioEssays 23: 716-724.

SARRAS, M.P., JR., MADDEN, M.E., ZHANG, X.M., GUNWAR, S., HUFF, J.K., HUDSON, B.G. (1991). Extracellular matrix (mesoglea) of hydra vulgaris. I. Isolation and characterization. Dev Biol 148: 481-494.

SARRAS, M.P., JR., YAN, L., GRENS, A., ZHANG, X., AGBAS, A., HUFF, J.K., ST JOHN, P.L., ABRAHAMSON, D.R. (1994). Cloning and biological function of laminin in hydra vulgaris. Dev Biol 164: 312-324.

SARRAS, M. P. J. (2012). Components, structure, biogenesis and function of the Hydra extracellular matrix in regeneration, pattern formation and cell differentiation. Int J Dev Biol 56: 567-576.

SCHALLER, H., GIERER, A. (1973). Distribution of the head-activating substance in hydra and its localization in membranous particles in nerve cells. J Embryol Exp Morphol 29: 39-52.

SCHALLER, H.C. (1973). Isolation and characterization of a low-molecular-weight substance activating head and bud formation in hydra. J Embryol Exp Morphol 29: 27-38.

SCHALLER, H.C., BODENMULLER, H. (1981). Isolation and amino acid sequence of a morphogenetic peptide from hydra. Proc Natl Acad Sci USA 78: 7000-7004

SCHALLER, H.C., HERMANS-BORGMEYER, I., HOFFMEISTER, S.A. (1996) Neuronal control of development in hydra. Int J Dev Biol 40: 339-344.

SCHALLER, H.C., HOFFMEISTER, S.A., DUBEL, S. (1989). Role of the neuropeptide head activator for growth and development in hydra and mammals. Development 107 Suppl: 99-107

SCHNEIDER, K.C. (1890). Histologie von hydra fusca mit besonderer berücksichtigung des nervensystems der hydropolypen. Arch mikrosk Anat 35: 321-379.

SCHUMMER, M., SCHEURLEN, I., SCHALLER, C., GALLIOT, B. (1992). HOM/ HOX homeobox genes are present in hydra (Chlorohydra viridissima) and are differentially expressed during regeneration. EMBO $\mathrm{J}$ 11: 1815-1823.

SHER, D., FISHMAN, Y., MELAMED-BOOK, N., ZHANG, M., ZLOTKIN, E. (2008) Osmotically driven prey disintegration in the gastrovascular cavity of the green hydra by a pore-forming protein. FASEB J 22: 207-214.

SHIMIZU, H. (2012). Transplantation analysis of developmental mechanisms in Hydra. Int J Dev Biol 56: 463-472.

SHIMIZU, H., AUFSCHNAITER, R., LI, L., SARRAS, M.P.J., BORZA, D.B., ABRAHAMSON, D.R., SADO, Y., ZHANG, X. (2008). The extracellular matrix of hydra is a porous sheet and contains type IV collagen. Zoology 111: 410-418.

SHIMIZU, H., ZHANG, X., ZHANG, J., LEONTOVICH, A., FEI, K., YAN, L., SARRAS, M.P.J. (2002). Epithelial morphogenesis in hydra requires de novo expression of extracellular matrix components and matrix metalloproteinases. Development 129: 1521-1532.

SHOSTAK, S., PATEL, N.G., BURNETT, A.L. (1965). The role of mesoglea in mass cell movement in Hydra. Dev Biol 12: 434-450.

SIEBERT, S., ANTON-ERXLEBEN, F., BOSCH, T.C. (2008). Cell type complexity in the basal metazoan Hydra is maintained by both stem cell based mechanisms and transdifferentiation. Dev Biol 313: 13-24.

SMITH, K.M., GEE, L., BLITZ, I.L., BODE, H.R. (1999). CnOtx, a member of the Otx gene family, has a role in cell movement in hydra. Dev Biol 212: 392-404.

SPEMANN, H., MANGOLD, H. (1924). Über die Induktion von Embryonalanlagen durch Implantation artfremder Organisatoren. Wilhem Roux's Arch Entw Mech 100: 599-638.

STEELE, R.E. (2002). Developmental signaling in Hydra: what does it take to build a "simple" animal? Dev Biol 248: 199-219.

STEELE, R.E. (2012). The Hydra genome: insights, puzzles, and opportunities for developmental biologists. Int J Dev Biol 56: 535-542.

SUGIYAMA, T. (1982). Roles of head-activation and head-inhibition potentials in pattern formation of Hydra: Analysis of a multi-headed mutant strain. Am Zool 22: 27-34.

SUGIYAMA, T., FUGISAWA, T. (1977a). Genetic analysis of developmental mechanisms in hydra. I. Sexual reproduction of Hydra magnipapillata and isolation of mutants. Growth Dev Differ 19: 187-200.

SUGIYAMA, T., FUJISAWA, T. (1977b). Genetic Analysis of Developmental Mechanisms in Hydra. III. Characterization of a regeneration deficient strain. J Embryo Exp Morphol 42: 65-77.

SUGIYAMA, T., FUJISAWA, T. (1978a). Genetic analysis of developmental mechanisms in Hydra. II. Isolation and characterization of an interstitial cell-deficient strain. J Cell Sci 29: 35-52. 
SUGIYAMA, T., FUJISAWA, T. (1978b). Genetic analysis of developmental mechanisms in hydra. V. Cell lineage and development of chimera hydra. J Cell Sci32:215-232.

TAKAHASHI, T., MUNEOKA, Y., LOHMANN, J., LOPEZDE HARO, M.S., SOLLEDER, G., BOSCH, T.C., DAVID, C.N., BODE, H.R., KOIZUMI, O., SHIMIZU, H., HATTA, M., FUJISAWA, T., SUGIYAMA, T. (1997). Systematic isolation of peptide signal molecules regulating development in hydra: LWamide and PW families. Proc Natl Acad Sci USA 94: 1241-1246.

TAKANO, J., SUGIYAMA, T. (1983). Genetic analysis of developmental mechanisms in hydra. VIII. Head- activation and head-inhibition potentials of a slow-budding strain (L4). J Embryol Exp Morphol 78: 141-168.

TAKANO, J., SUGIYAMA, T. (1984). Genetic analysis of developmental mechanisms in hydra. XII. Analysis of chimaeric hydra produced from a normal and a slowbudding strain (L4). J Embryol Exp Morphol 80: 155-173.

TANNREUTHER, G. (1908). The development of Hydra. Biol Bull 14: 261-281.

TARDENT, P. (1954). Axiale Verteilungs. Gradienten der interstitielle Zellen bei Hydra und Tubularia und ihre Bedeutung für die Regeneration. Roux'Arch EntwMech Org 146: 593-649.

TARDENT, P. (1995). The cnidarian cnidocyte, a high-tech cellular weaponry. BioEssays $17: 351-362$.

TECHNAU, U., BODE, H.R. (1999). HyBra1, a Brachyury homologue, acts during head formation in Hydra. Development 126: 999-1010.

TECHNAU, U., CRAMER VON LAUE, C., RENTZSCH, F., LUFT, S., HOBMAYER, B., BODE, H.R., HOLSTEIN, T.W. (2000). Parameters of self-organization in Hydra aggregates. Proc Natl Acad Sci USA 97: 12127-12131.

TECHNAU, U., MILLER, M.A., BRIDGE, D., STEELE, R.E. (2003). Arrested apoptosis of nurse cells during hydra oogenesis and embryogenesis. Dev Biol260: 191-206.

TREMBLEY, A. (1744). Mémoires pour servir à l'histoire d'un genre de polypes d'eau douce, à bras en forme de cornes. Jean \& Herman Verbeek, Leiden.

TURING, A. (1952). The chemical basis of morphogenesis. Phil Trans $R$ Soc B 237: 32-72.

VENN, A.A., LORAM, J.E., DOUGLAS, A.E. (2008). Photosynthetic symbioses in animals. J Exp Bot 59: 1069-1080.

WATSON, W. (1753). A treatise upon coral, and several other productions furnish'd by the sea, in order to illustrate the natural history thereof, by the Sieur de Peyssonnel. Philos Trans 47: 447-469.
WEBSTER, G. (1966a). Studies on pattern regulation in hydra. II. Factors controlling hypostome formation. J Embryol Exp Morphol 16: 105-122.

WEBSTER, G. (1966b). Studies on pattern regulation in hydra. III. Dynamic aspects of factors controlling hypostome formation. J Embryol Exp Morphol 16: 123-141.

WEILL, R. (1934a). I. Recherches sur les nématocystes (morphologie, physiologie développement), Contribution à l'étude des cnidaires et de leurs nématocystes. Travaux Station Zoologie de Wimereux, Bordeaux, France.

WEILL, R. (1934b). II. Valeur taxonomique du cnidome., Contribution à l'étude des cnidaires et de leurs nématocystes. Travaux Station Zoologie de Wimereux Bordeaux, France, pp. 351-701.

WEIS, V.M., ALLEMAND, D. (2009). Physiology. What determines coral health? Science 324: 1153-1155.

WEISMANN, A. (1883). The origin of the sexual cells in hydromedusae (Foreign title: Die Entstehung der Sexualzellen bei Hydromedusen). Gustav Fischer, Jena.

WESTFALL, J.A., YAMATAKA, S., ENOS, P.D. (1971). Ultrastructural evidence of polarized synapses in the nerve net of Hydra. J Cell Biol 51: 318-323.

WHITNEY, D.D. (1907). Artificial Removal of the Green Bodies of Hydra viridis. Biol Bull 13: 291-299.

WITTLIEB, J., KHALTURIN, K., LOHMANN, J.U., ANTON-ERXLEBEN, F., BOSCH T.C. (2006). Transgenic Hydra allow in vivo tracking of individual stem cells during morphogenesis. Proc Natl Acad Sci USA 103: 6208-6211.

WOLPERT, L. (1969). Positional information and the spatial pattern of cellular differentiation. J Theor Biol 25: 1-47.

WOLPERT, L., CLARKE, M.R.B., HORNBRUCH, A. (1972). Position signalling along Hydra. Nature 239: 101-105.

WOOD, R.L. (1961). The fine structure of intracellular and mesoglea attachments of epithelial cells in Hydra. In The biology of hydra and some other coelenterates. (Ed: Lenhoff, H.M., Loomis, W.F.), Miami Press University, Coral Gables, Fla.

YAO, T. (1945). Studies on the organizer problem in Pelmatohydra oligactis. I. The induction potency of the implants and the nature of the induced hydranth. $J$ Exp Biol 21: 145-150.

YOSHIDA, K., FUJISAWA, T., HWANG, J.S., IKEO, K., GOJOBORI, T. (2006). Degeneration after sexual differentiation in hydra and its relevance to the evolution of aging. Gene 385: 64-70.

ZIHLER, J. (1972). Zur gametogenes und befruchtungsbiologie von hydra. Roux Arch Dev Biol 169: 239-267. 


\section{Further Related Reading, published previously in the Int. J. Dev. Biol.}

An insulin-like peptide regulates size and adult stem cells in planarians

Claire M. Miller and Phillip A. Newmark

Int. J. Dev. Biol. (2012) 56: 75-82

Synergy between two transcription factors directs gene expression in Dictyostelium tip-organiser cells

Hong Yu Wang and Jeffrey G. Williams

Int. J. Dev. Biol. (2010) 54: 1301-1307

Diffusible gradients are out - an interview with Lewis Wolpert

Michael K. Richardson

Int. J. Dev. Biol. (2009) 53: 659-662

Metamorphosis of Hydractinia echinata (Cnidaria) is caspase-dependent Stefanie Seipp, Karola Wittig, Beate Stiening, Angelika Böttger and Thomas Leitz Int. J. Dev. Biol. (2006) 50: 63-70

Cnidarians as a model system for understanding evolution and regeneration Brigitte Galliot and Volker Schmid

Int. J. Dev. Biol. (2002) 46: 39-48

Pattern regulation properties of a Hydra strain which produces additional heads along the body axis

$S$ Zeretzke and S Berking

Int. J. Dev. Biol. (2001) 45: 431-439

Formation and maintenance of the organizer among the vertebrates

$\mathrm{K}$ Joubin and C D Stern

Int. J. Dev. Biol. (2001) 45: 165-175

Neuronal control of development in hydra

H C Schaller, I Hermans-Borgmeyer and S A Hoffmeister

Int. J. Dev. Biol. (1996) 40: 339-344

5 yr ISI Impact Factor $(2011)=2.959$

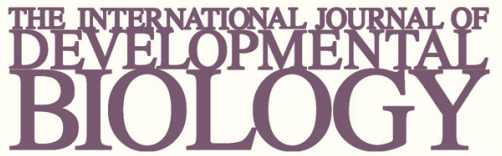

Volume 54 Nos. $6 / 7$
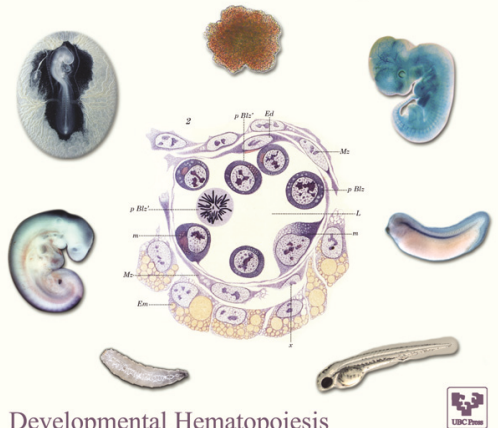

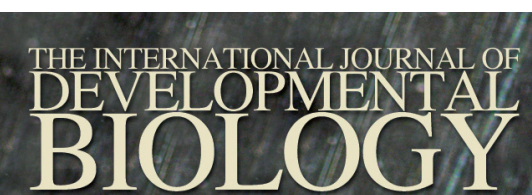

Volume 56 Nos. $1 / 2 / 3$

Special Issue

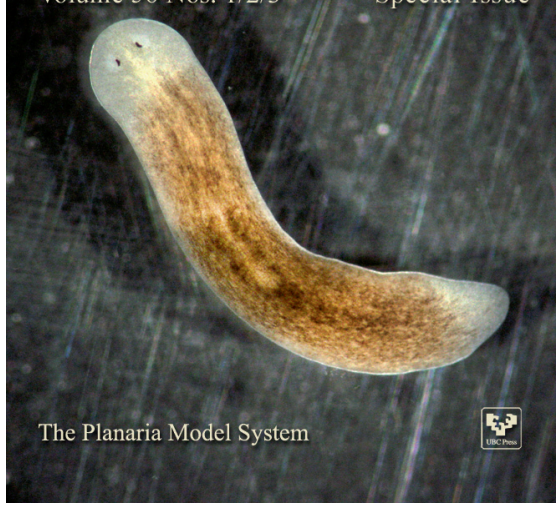

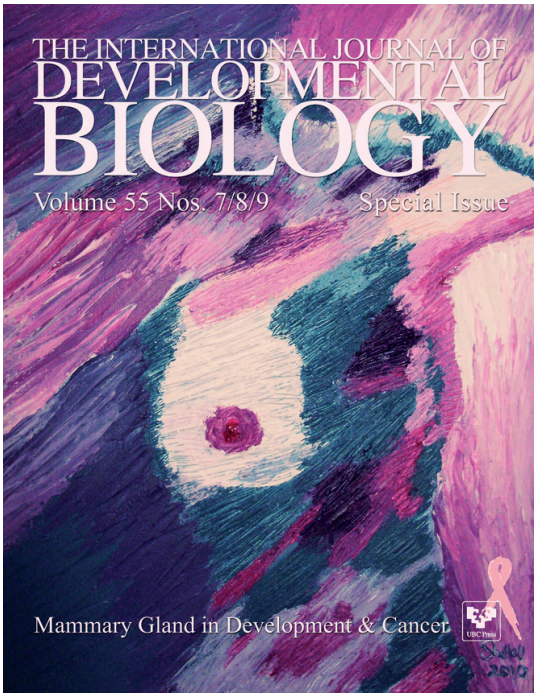

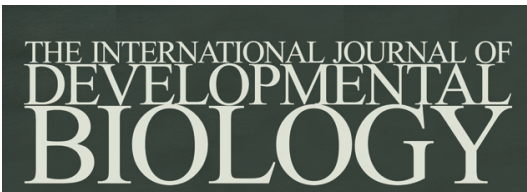

Volume 55 Nos. $4 / 5$

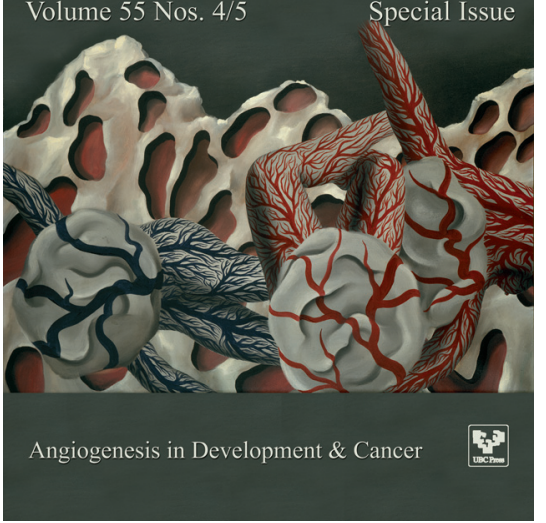

